Journal of Ancient Philosophy ISSN 1981-9471 - FFLCH/USP www.revistas.usp.br/filosofiaantiga
J. anc. philos. (Engl. ed.), São Paulo, v.13, n.2. p. 01-34, 2019.

DOI: http://dx.doi.org/10.11606/issn.1981-9471.v13i2p01-34

\title{
Departing from Perfect Goodness? The tetragonōs and the hugiēs man in Plato's Protagoras
}

Elena Irrera

Simonides' well known Ode to Scopas, which Plato introduces in the Protagoras, provides fertile ground for a discussion of two different forms of human goodness: on the one hand, the excellence

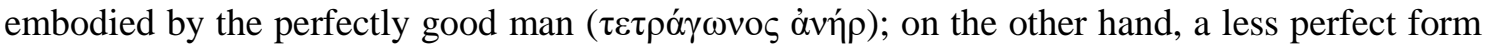

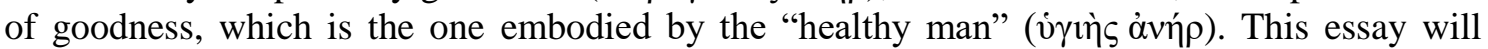
critically address the shift from perfect to imperfect goodness and its underlying reasons. More specifically, I will argue that the distinctive goodness of the "healthy man" can be identified with a form of "minimal political decency". As such, this can be praised only in comparison to a condition of lawlessness.

\section{Introduction}

Simonides, born in Kea island from an aristocratic family, lived approximately between 556 and 468 a.C. He is generally hailed as one of the most successful representatives of choral lyric poetry, a literary trend whose span runs from the poet Alcman in the archaic period $\left(7^{\text {th }}\right.$ century B.C.) - to Timotheos in the classical period (beginning of $4^{\text {th }}$ century). His Ode (or Encomium ${ }^{1}$ ) to Scopas, which Plato introduces as

\footnotetext{
${ }^{1}$ The above mentioned piece was widely known as an "encomium" (Starting from Gentili, Bruno. "Studi su Simonide." Maia 16(1964), pp. 278-304: 295-296). Being a well-established form of poetic composition in Greek Archaic age, the encomium was generally used to commemorate noble deeds. As such, it could serve not only as the repository of the society's record of its past, but also as a "storehouse" of information concerning the ethical principles in force in Greek society (see Segal, Charles P. "Song, Ritual, and Commemoration in Early Greek Poetry and Tragedy." Oral Tradition 4, 3(1989): 330-359). Only a few scholars have expressed reservation about the classification of the Simonidean poem as an encomium. See for instance Bowra (Bowra, Cecil M. "Simonides and Scopas." Classical Philology 29(1934): 230-239), who considers it to be a skolion, i.e. as one sung by invited guests at banquets (cf. Dickie, M. "The Argument and Form of Simonides 542 PMG." Harvard Studies in Classical Philology 82(1978), pp. 21-33: 2122, who takes it as an occasional poem composed to be performed as an encomium at a banquet). See also Parry (Parry, Hugh. "An Interpretation of Simonides 4 (Diehl)", Transactions of the American Philological Association 96(1965), pp. 297-320: 298-299), who does not deny that the
} 
Journal of Ancient Philosophy ISSN 1981-9471 - FFLCH/USP www.revistas.usp.br/filosofiaantiga
J. anc. philos. (Engl. ed.), São Paulo, v.13, n.2. p. 01-34, 2019.

DOI: http://dx.doi.org/10.11606/issn.1981-9471.v13i2p01-34

the subject of several exegetic attempts in Plato's Protagoras, provides valuable philosophical insights into two of the possible forms that human goodness can assume. The first consists in the image of a perfectly good man ( $\dot{\alpha} \gamma \alpha \theta \dot{\alpha} \varsigma \dot{\alpha} v \eta \dot{\rho} \rho)$, square ( $\tau \varepsilon \tau \rho \alpha ́ \gamma \omega v o \varsigma)$ in hands and feet and mind, constructed without a flaw ${ }^{2}$ (Fr. 542.1-3 PMG; Fr. 4 Diehl; cf. Plato, Prot. 339b1-3; 344a2-3). The second is the image of a "healthy"

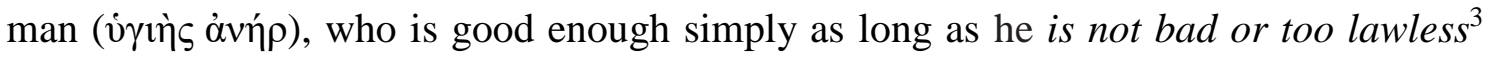
and knows polis-benefiting justice (542.34-36 PMG; cf. Plato, Prot. 346c2-9). The typical behaviour of the "healthy man", consisting in sheer abstinence from injustice, departs from the one exhibited by the so-called "four-squared" man, who embodies human goodness at its finest. More specifically, while the first image stresses the highest conceivable peak of human excellence, the second denotes a less demanding degree of goodness.

The present essay aims not only to pinpoint the shift from Simonides' account of perfect goodness to the second, less perfect ethical ideal emphasized in the poem and its underlying reasons, but also to inquire into the Socratic employment of the two Simonidean accounts and the message/s he means to convey by way of his exegetic analysis. I will propose that Socrates does not mean so much to praise one ideal at the expenses of the other as to present two different ways of speaking of moral goodness. In Socrates' view, the morally perfect man and the "healthy" man may represent respectively the highest and the lowest level of moral goodness which a man can ideally embody across his life. Within such a theoretical framework,

(a) perfect virtue is presented as something which is possible to acquire, despite the costs and efforts involved in its acquisition.

poem might contain a praise of Scopas but advances the possibility that the poem is a "consolatory piece".

${ }^{2}$ In this paper I shall adopt a slightly modified version of the Arieti's and Barrus' translation (Arieti, James A. and Barrus, Roger M. (eds.) Plato's Protagoras (Rowman and Littlefield Publishers 2010), p. 97), from which all the passages of the Protagoras quoted in this essay will be taken, unless differently specified. The edition of the Greek text I employ is by Denyer (Denyer Nicholas (ed. By). (2008) Plato. Protagoras (Cambridge University Press 2008).

${ }^{3}$ In this paper I shall replace Arieti's and Barrus' translation of " $\alpha \dot{\alpha} \alpha \dot{\lambda} \alpha \mu \nu \varsigma^{\prime}$ " as "inept" with Lamb's translation "lawless" (see Lamb, Walter Rangeley Maitland, ed. by Protagoras, in Plato. Plato in Twelve Volumes, Vol. 3 (London: William Heinemann Ltd 1967)). 
Journal of Ancient Philosophy ISSN 1981-9471 - FFLCH/USP www.revistas.usp.br/filosofiaantiga
J. anc. philos. (Engl. ed.), São Paulo, v.13, n.2. p. 01-34, 2019.

DOI: http://dx.doi.org/10.11606/issn.1981-9471.v13i2p01-34

(b) the virtue of the "healthy" man can be thought of not only as a moral attitude, but also as distinctively political virtue, one identifiable as a form of "minimal political decency". As such, this can be praised only in comparison to a condition of lawlessness.

In the first part I supply some information about the structure of the Simonidean poem and attempt a reconstruction of the theoretical image of the perfectly virtuous man and its distinctive features. My investigation will address both the original verses of the first two strophes of the poem and some of the relative exegetical remarks advanced by Socrates in the Protagoras. In the second part of the essay I will argue that the paradigm of "imperfect moral goodness" expresses a virtual threshold of human political agency, namely one below which a person cannot either be praised or regarded as "good". I hope to show that, by availing himself of the two Simonidean images of human goodness, Socrates lays the ground for an anthropology of virtue bounded by a maximum and a minimum degree of goodness, and also that he does so without distorting Simonides' message. I will propose that the ultimate intention of the Platonic Socrates in using Simonides' poem is to offer further articulation and clarity to the Protagorean idea of a "minimum sense of justice" that can be derived from a reading of Prot. 320c6-328d1. This minimum level of virtue, if not supported by an adequate education, cannot accepted by Socrates as a commendable ideal.

\section{The poem: text and structure}

Before undertaking the tasks proposed in this essay, some words about the structure of the poem are in order. It is generally agreed that the Ode to Scopas has come down to us incomplete ${ }^{4}$, so that it must be classed as a large fragment rather than a whole poem. ${ }^{5}$ The traditional strophic arrangement of the Ode is the one proposed by those editors (like Diehl, Page, Aars, and Edmonds) who have preserved the same order of quotation of the verses contained in Plato's Protagoras. On the reconstruction of the poem proposed in the collection of Greek lyric poems Poetae Melici Graeci (edited by

\footnotetext{
${ }^{4}$ Woodbury (Woodbury, Leonard. "Simonides on Arete." Transaction and Proceedings of the American Philological Association 84(1953), pp. 135-163: 139) suggests that the poem "was well known in the fifth century, but not wholly preserved because it was too well known to quote in full”.

${ }^{5}$ See Parry 1965: 297.
} 
Journal of Ancient Philosophy ISSN 1981-9471 - FFLCH/USP www.revistas.usp.br/filosofiaantiga
J. anc. philos. (Engl. ed.), São Paulo, v.13, n.2. p. 01-34, 2019.

DOI: http://dx.doi.org/10.11606/issn.1981-9471.v13i2p01-34

Page; $P M G$ 542), its verses fall into four stanzas, the first of which is taken to lack seven lines. ${ }^{6}$ The arrangement proposed in $P M G 542$ (the most widely accepted by scholars, which I shall adopt myself in the present essay) is the following:

[T] o become a good man truly is difficult, in hands and feet and mind square, fashioned without fault; [seven verses are missing] nor to me is the Pittacus-thing harmoniously circulated, although said by a wise man; he said that it is difficult to be noble. A god alone would have this gift. It is not possible for a man not to be bad, [a man] whom intractable disaster takes down; Faring well, every man is good, but bad if [faring] badly, and for the most part best [are the men] whom the gods love.

Therefore not ever shall I, searching for what cannot come into being, toss a share of my life onto an empty impractical hope, [the hope of] an entirely blameless man, among all of us

who reap the solidly founded earth.

But if I should find him I'll let you know.

But I praise and love all, whoever willingly does nothing ugly; and not even do the gods fight with necessity. I am not a lover of blame. For me it is fitting that a man not be wicked nor completely lawless, [a man] understanding justice [a thing] useful to the state, a healthy man; and him I shall not blame; you see, [there are] generations of numberless fools; all things are fair, [the things] with which ugly things are not $\operatorname{mixed}^{7}$.

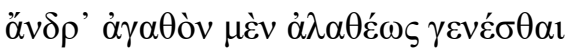

\footnotetext{
${ }^{6}$ As Giuliano (Giuliano, F.M. "Esegesi letteraria in Platone: la discussione sul carme simonideo nel Protagora." 41(1992), pp. 105-190: 114, footnote 32) explains by quoting WilamowitzMollendorf, Christ, Parry and Schwenk, the lacuna identifiable in the verses 4-10, as well as the one in verses 31-2 of the Page edition, might not have illustrated anything relevant in terms of content.

${ }^{7}$ Translation by Arieti and Barrus in Appendix C (Arieti and Barrus 2010: 119-120). I replace "shameful" with "ugly". The reasons for my choice are briefly explained in footnote 45 of this paper.
} 
Journal of Ancient Philosophy ISSN 1981-9471 - FFLCH/USP

www.revistas.usp.br/filosofiaantiga
J. anc. philos. (Engl. ed.), São Paulo, v.13, n.2. p. 01-34, 2019.

DOI: http://dx.doi.org/10.11606/issn.1981-9471.v13i2p01-34

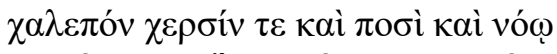

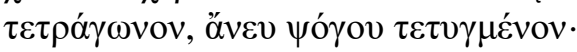

5

[

[

[

10[

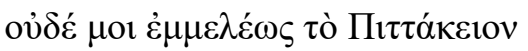

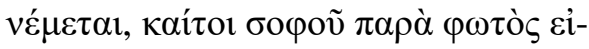

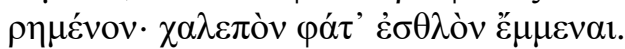

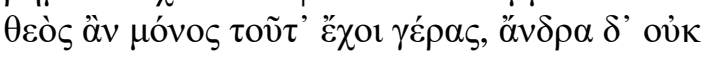

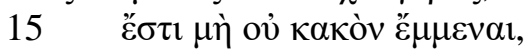

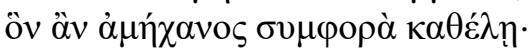

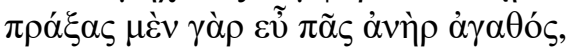

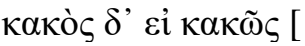

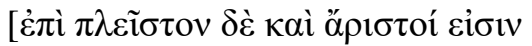

20 [oúc àv oi $\theta \varepsilon o i ̀ ~ \varphi ı \lambda \tilde{\omega} \sigma ı v$.

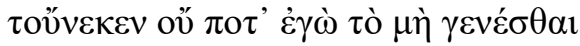

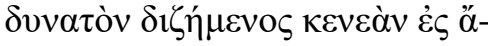

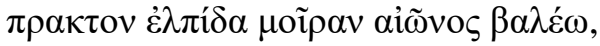

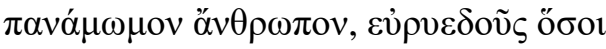

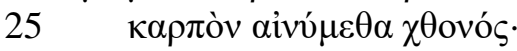

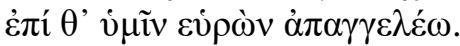

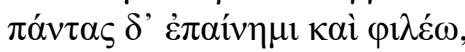

$\dot{\varepsilon} \kappa \omega े \nu$ ő $\tau \tau 1 \varsigma \check{\varepsilon} \rho \delta \eta$

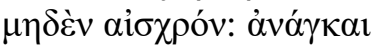

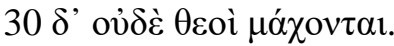

[

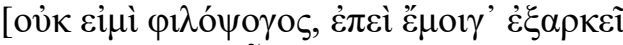

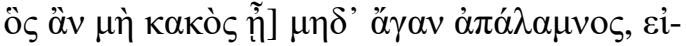

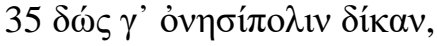

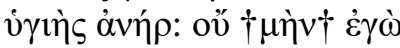

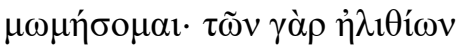

$\dot{\alpha} \pi \varepsilon \dot{\rho} \rho \omega v \gamma \varepsilon v \varepsilon \dot{\varepsilon} \theta \lambda \alpha$.

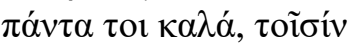

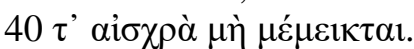

Only a few scholars propose alternative arrangements of the Simonidean verses.

Beresford, for instance, hypothesizes that the poem falls in three stanzas instead of four, and argues that the seven lines of the first stanza of the poem traditionally regarded as missing are verses $10-14$ of strophe 2 of the $P M G$ edition, whereas verses 24-28 would 
Journal of Ancient Philosophy ISSN 1981-9471 - FFLCH/USP www.revistas.usp.br/filosofiaantiga
J. anc. philos. (Engl. ed.), São Paulo, v.13, n.2. p. 01-34, 2019. DOI: http://dx.doi.org/10.11606/issn.1981-9471.v13i2p01-34

fall in strophe 2. ${ }^{8}$ Others, instead, believe that the section of the song corresponding to $P M G$ 542.33-40 constitutes an epode, that is, the conclusive strophe of a triad (the other strophes being the thesis and the antithesis). ${ }^{9}$ Among them, Gentili suggests that only a very short part of Simonides' poem is mentioned in Plato's Protagoras, so that the whole first triad would be omitted, with the exception of the 3 initial verses of the first strophe. As he believes, $P M G 542.33-40$ would be the epod of the second triad of the poem, which expresses an ideal of goodness antitethical to the one of perfect virtue supposedly illustrated in the first one. ${ }^{10}$ The possibility that the poem be originally longer than the stanzas into which it is generally credited to fall, however, is not entirely credible, especially if we consider that in Protagoras 344b3 Socrates proposes to investigate the poem's general outline and intent - a declaration of purpose which might imply that at least part of every stanza is going to be included in his exegetic analysis. ${ }^{11}$

As far as the purpose of the poem is concerned, the issue has sparked scholarly controversy in several aspects. While some readers believe that the human ideal of the "imperfect", "healthy" man is the primary object of Simonides' praise ${ }^{12}$, others maintain

\footnotetext{
${ }^{8}$ See Beresford (Beresford, Adam, "Nobody's Perfect: A New Text and Interpretation of Simonides PMG 542." Classical Philology 103,3(2008): 237-256. More details of his reconstruction will be supplied in footnote 26 of this paper).

${ }^{9}$ For a detailed discussion and criticism of this view see Giuliano 1992: 113-114, footnote 32.

${ }^{10}$ See Gentili 1964, especially 288.

${ }^{11}$ See Parry 1965: 316.

${ }^{12}$ As it has been suggested by Carson (Carson, Anne. "How Not to Read a Poem: Unmixing Simonides from 'Protagoras'." Classical Philology 87,2(1992): 110-130), the main intention of the poem is not to offer a simple description of virtue and its forms, but to praise one of those forms, namely the less demanding form of moral goodness. See for instance Adam and Adam (Adam, James and Adam, Adele M. Platonis Protagoras. With Introduction, Notes and Appendices. Cambridge University Press 1893), who speak of "the easy-going morality of the poem". Cf. Smyth (Smyth, Herbert.Weir. Greek Melic Poets (Macmillan and co 1900), pp. 311312). Wilamowitz-Moellendorff (Wilamowitz-Moellendorff, Ulrich von. Sappho und Simonides: Untersuchungen über griechische Lyriker (Weidmann 1913), pp. 175-176) maintains that Simonides describes an older aristocratic ideal in the first strophe of his poem, which he replaces with a new, more "ethical" one (this aspect of his view is highlighted by Beresford 2008: 238, footnote 3). See also Donlan (Donlan, Walter. "Simonides, Fragment 4D and P. Oxy. 2432." Transactions and Proceedings of the American Philological Association 100(1969), pp. 71-95: 75-87), who agrees that Simonides is attacking the aristocratic ideal of virtue, although believing that in the first strophe the poet is referring to the newer (political) ideal, not to the aristocratic one. Cf. Bowra (1934: 235-239), who contends not only that Simonides means to praise the virtue of the "healthy man", but also that the nature of that virtue is eminently political. Beresford, instead, considers the Simonidean poem as an invitation to pursue the ethical life of a "healthy"
} 
Journal of Ancient Philosophy ISSN 1981-9471 - FFLCH/USP www.revistas.usp.br/filosofiaantiga
J. anc. philos. (Engl. ed.), São Paulo, v.13, n.2. p. 01-34, 2019.

DOI: http://dx.doi.org/10.11606/issn.1981-9471.v13i2p01-34

that the poet's first and most authentic concern is for the image of the man of outstanding excellence outlined in the first two strophes. ${ }^{13}$ In principle, this type of man is not impossible to find in real life (consider for instance the verse "if I find one [i.e. a permanently virtuous man in the perfect sense] I will let you know" in PMG 542.26), and it is not to be excluded that Simonides himself intends to endorse the image of a morally faultless man as a normative paradigm of attainable virtuous agency to which it is worth sticking.

On the other hand, it is undeniable that the he appears committed to stressing some difficulties related to the achievement of such a perfect ideal, as well as the impossibility to preserve perfect virtue across a lifespan when severely bad circumstances befall a good man. As a matter of fact, Simonides throws into sharp relief the benefits of a modest, less demanding ideal of virtue, and in the Ode he unequivocally presents the goodness proper to the man neither too wicked nor inept, i.e. the "healthy" (i̛⿱ís) man, as a more practicable option than the one of perfect excellence embodied by the "square" man "in hands, feet, and mind".

The attention paid by the poet to the morally imperfect man is likely to be justified by the occasion and the reasons for the composition of the poem. Being probably written around 513-510 b.C. ${ }^{14}$, the Ode was addressed to Scopas, son of the Thessalian king Creon, a man outstanding in power and wealth and yearning for celebration. ${ }^{15}$ Although the aims of the poem remain dubious, some scholars have suggested that Simonides' insistence on the difficulty of being perfectly good represents a warning for the king not

man as a more practicable ideal than one of perfect excellence, without entailing that the "less demanding virtue" is of political nature (2008).

${ }^{13}$ See Dickie (1978: 23-26), according to whom Simonides endorses the older aristocratic standard, although admitting that it is too difficult to attain. A similar view is held by Woodbury (1953: 153). See also Frede (Frede, Dorothea. "The Impossibility of Perfection: Socrates' Criticism of Simonides' Poem in the Protagoras." 39, 4(1986), pp. 729-753: 738), who says that Simonides, although stressing the idea that human virtue is imperfect if compared to the one of the gods (a traditional topic that can be traced to Homer), supports a certain re-evaluation of old values. As Frede points out, not only does Simonides suggest that goodness depends on external conditions of fortune, but also proposes that the inner attitude determines the worth of a person.

${ }^{14}$ On the issue of the date of composition of the poem I refer the reader to Johnston, Richard W. and Mulroy, David D. "Simonides' Use of the Term TETPAГ $2 N O \Sigma$." Arethusa 37, 1(2004), pp. 1-10: 2 , footnote 3 .

${ }^{15}$ On Scopas' desire for honour and his request to Simonides see Cicero, De Oratore 2.86.352. 
Journal of Ancient Philosophy ISSN 1981-9471 - FFLCH/USP www.revistas.usp.br/filosofiaantiga
J. anc. philos. (Engl. ed.), São Paulo, v.13, n.2. p. 01-34, 2019.

DOI: http://dx.doi.org/10.11606/issn.1981-9471.v13i2p01-34

to be too self-demanding in terms of general ethical conduct ${ }^{16}$, whereas others have proposed that the poet endeavours to free Scopas from an accusation of specific acts of injustice ${ }^{17}$, or simply to console him for his lack of perfect virtue. ${ }^{18}$ Given the political role held by Scopas, it has even been suggested that the poet aims to supply him with an ethical code that may excuse a persistent policy of oppression. ${ }^{19}$

A different question is the purpose for which the Platonic Socrates employs his verses. Does Socrates' apparent insistence on the figure of the healthy man betray a sheer willingness to give his interlocutors a display of his hexegetic ability? Alternatively, should we suppose that Socrates himself means to underscore two different ways of understanding human goodness? If that is the case, what practical relevance of each model of goodness does he present? As I believe, Socrates might appeal to Simonides' poem mainly as a suitable basis for discussion on political virtue within a democratic framework - one which admits of various levels of human goodness and finds its starting point in a minimal degree of moral and civic decency. As I hope it will emerge in the last section of this essay, I hope to articulate the view that, when it comes to decency (understood as a minimal level of civic goodness), Simonides' appeal to it might be used by Socrates to better articulate Protagoras'view of virtue as a good in which every citizen (although to different degrees) takes part.

\section{Understanding the poem within the Platonic Philosophical Framework}

Before undertaking a critical discussion of the two ideals of goodness sketched out by Simonides in his Ode to Scopas, a few words on the context in which Plato places the Simonidean fragments are needed. In the central section of the Protagoras, Socrates

\footnotetext{
${ }^{16}$ See for instance Snell 1961: 52. See also Buongiovanni 1998, who argues that both the image of perfect virtue (which is difficult, but not impossible to achieve) and the one of the healthy man are meant to highlight the value of the tyrant Scopas, both in fortunate and in less fortunate circumstances. The author claims that this approach is in line with the literary tradition of Archaic choral lyric poetry (e.g. Pyndar and Bacchilides).

${ }^{17}$ See Schneidewin, Friederich W. Simonides Cei Carminum Reliquiae (Vieweg and Son 1885), pp. 21-22.

${ }^{18}$ See Parry $(1965: 298,310)$, who points out that the consolatory tone of the poem might have been sparked by a specific (although unknown) occasion. See also Frede 1986: 738.

${ }^{19}$ See Smyth 1900, pp. 311-312.
} 
Journal of Ancient Philosophy ISSN 1981-9471 - FFLCH/USP www.revistas.usp.br/filosofiaantiga
J. anc. philos. (Engl. ed.), São Paulo, v.13, n.2. p. 01-34, 2019.

DOI: http://dx.doi.org/10.11606/issn.1981-9471.v13i2p01-34

and the sophist Protagoras confront each other on the issue of the teachability of virtue by way of critical exegesis of the poetic composition at issue. The initiative to engage in interpretation of poetic verses is undertaken by Protagoras, who openly admits being a teacher of virtue (Prot. 316c5-d3; 317b2-5; 318a5-8) and professes himself to be strongly convinced that a man's education, in its greatest part, consists in being skilled in the matter of poetic verses (Prot. 338e7-8). Having illustrated the main tenets of Simonides' poem, Protagoras expects Socrates to agree that a logical inconsistency occurs between two strophes. In the first strophe (Prot. $339 \mathrm{~b} 1-3^{20}$ ) we read that

$[\mathrm{O}] \mathrm{n}$ the one hand, for a man to become good truly is difficult, Square in hands and feet and mind, constructed without a flaw. ${ }^{21}$

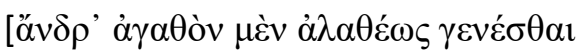

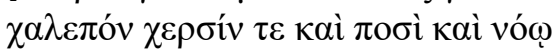

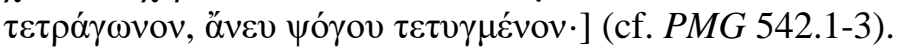

In the second strophe (Prot. 339c3-5) Simonides addresses a saying of Pittacus of Mytilene, an aristocratic statesman and military commander better known as one of the Seven Wise Men of ancient Greece (and equally famous for being an enemy of tyranny). ${ }^{22}$ Disagreeing with his views, Simonides says:

$[\mathrm{N}]$ or for me is the Pittacus-view harmoniously circulated, although said by a wise man - he said that being noble is difficult.

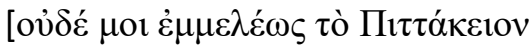

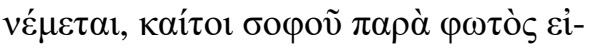

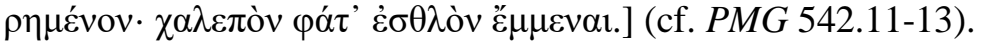

Socrates is asked to take part in the conversation by answering the following question: how can Simonides claim that it is indeed hard to become a perfectly good man and, all the same, criticize Pittacus for expressing the same view without contradicting himself? In order to give the poem logical consistency - to the effect of offering equally reasonable exegetical solutions - Socrates proposes three tentative readings. Initially, Socrates asks for the virtual help of Simonides' well-known fellow-citizen Prodicus of

\footnotetext{
${ }^{20}$ Cfr. fragment 37 Diehl.

${ }^{21}$ Unless differently specified, translation used in this paper is by Arieti and Barrus (2010).

22 The informations above are taken from Diogenes Laertius, Lives and Opinions of Eminent Philosophers I, 74-81. Regarding Pittacus' adversion for tyranny, in I, 74 the author reports that Pittacus, aided by the brothers of Alcaeus, Pittacus, overthrew Melanchrus, tyrant of Lesbos.
} 
Journal of Ancient Philosophy ISSN 1981-9471 - FFLCH/USP www.revistas.usp.br/filosofiaantiga
J. anc. philos. (Engl. ed.), São Paulo, v.13, n.2. p. 01-34, 2019.

DOI: http://dx.doi.org/10.11606/issn.1981-9471.v13i2p01-34

Ceos, who lived between 465 BC and 395BC (340a7-8). As Socrates believes, Protagoras has failed to realize that there is a neat semantic difference between the " $\gamma \varepsilon v \varepsilon \dot{\sigma} \sigma \theta \alpha$ l

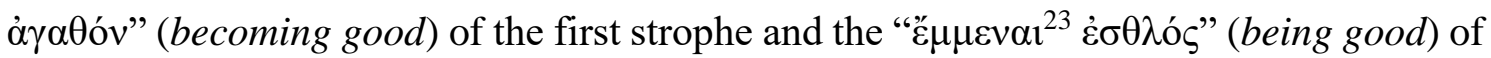
the second one. It is at Prot. 340c3-d1 that Socrates explains the apparent discrepancy between the two strophes away:

$[\mathrm{P}]$ ittacus was not saying that it was difficult to become noble, as Simonides was saying, but to be [noble]; and these are not the same, Protagoras, as our Prodicus here says - to be and to become. And unless to be and to become are the same thing, Simonides himself is not saying things opposite to himself.

Socrates suggests that the two strophes would contradict each other only if Simonides claimed that being a good man is a difficult task. This, however, is not the case. As Socrates maintains, while being a good man is for Simonides an easy task, becoming a good man is not.

In support of his view, Socrates quotes the poet Hesiod:

[A]nd perhaps our Prodicus here and many others would say, in accordance with Hesiod, that to become good is difficult, 'that before excellence the gods have put sweat,' but when [someone] has come to the height [of excellence], then it is easy to be there, though it was difficult [before] [Hesiod, Works and Days 289; cf. Plato, Republic 364c5-d3] (Prot. 340d1-4).

Whether Socrates' exegesis is to be taken seriously or not ${ }^{24}$, several plausible reasons for excluding that Simonides is contradicting himself in the poem have been advanced in the relevant secondary literature. A possible solution is expressed by Schütrumpf in his Simonides 542 PMG. Schütrumpf maintains that - pace Socrates - no real distinction between "being" and "becoming" virtuous is drawn in the Simonidean poem. Schütrumpf argues that, in the first strophe, Simonides is simply providing a preliminary and revisable opinion on virtue - presumably the highest and most perfect virtue - whereas in the second strophe he simply changes his view and stresses that, after careful consideration, being virtuous appears to be not just difficult, but really impossible,

\footnotetext{
${ }^{23}$ Epic form of $\varepsilon \tilde{v} v \alpha 1$.

${ }^{24}$ According to some, the distinction between "becoming good" and "being good" might have been introduced in the Protagoras either as a "play" (see Gundert 1952: 71 and von WilamowitsMollendorf 1913, p. 47 quoted by Giuliano 1992: 106, footnote 4) or a "parody" (see Taylor, Christopher C.W. (translated with notes). Plato, Protagoras, (Oxford University Press 1976, p. 145). Both cases would exclude the possibility of involuntary exegetical mistakes on Plato's part.
} 
Journal of Ancient Philosophy ISSN 1981-9471 - FFLCH/USP www.revistas.usp.br/filosofiaantiga
J. anc. philos. (Engl. ed.), São Paulo, v.13, n.2. p. 01-34, 2019.

DOI: http://dx.doi.org/10.11606/issn.1981-9471.v13i2p01-34

given the plethora of unforeseeable, negative events which generally turn a good man into a reprehensible one. Being permanently virtuous, then, would be an exclusive prerogative of god.

An alternative solution is proposed by Beresford (already mentioned in section 2 of this paper) in his essay Nobody's perfect. Like Schütrumpf, Beresford contends that no distinction is drawn between "being" and "becoming" virtuous in the Ode to Scopas, and he suggests that it the only object of Simonides' concern is "being permanently virtuous". ${ }^{25}$ Unlike Schütrumpf, though, Beresford considers the Pittachean being

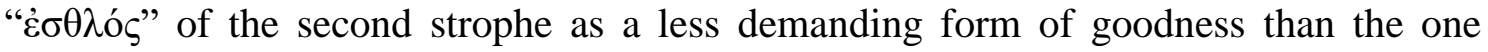
represented by the " $\alpha \gamma \alpha \theta$ ó $\varsigma$ " man of the first strophe. By saying in the first strophe that to be virtuous in the perfect sense is "difficult", Simonides would actually mean that it is "impossible". By contrast, through the disagreement with Pittacus expressed in the second strophe, he would imply that being virtuous in a less perfect sense is neither difficult nor impossible, but easy. That is the reason why the virtue of the \&̇ $\sigma \theta \lambda$ ó $\varsigma$ man, unlike the one embodied by the $\tau \varepsilon \tau \rho a ́ \gamma \omega v o \varsigma$ man, would be achievable.

In my opinion, both interpretations elicit substantial problems. In the first place, none of them takes seriously the idea that the difference between "becoming"

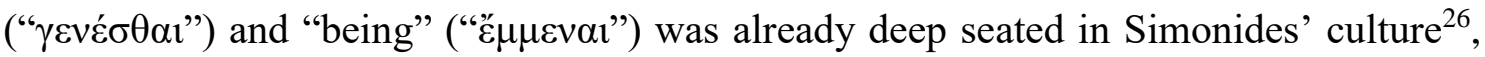

\footnotetext{
${ }^{25}$ It is precisely this view that prompts Beresford to suggest an alternative arrangement of the verses of the Simonidean poem (as shown already in section 2 of the present paper) and to deny that seven lines of the poem are missing in the first strophe. Beresford's alternative arrangement is therefore the following: «For a man it's certainly hard to be truly good-perfect in hands, feet, and mind, built without a single flaw; only a god can have that prize; but a man, there's no way he can help being bad when some crisis that he cannot deal with takes him down. Any man's good when he's doing well in life, bad when he's doing badly, and the best of us are those the gods love most. But for me that saying of Pittacus doesn't quite ring true (even though he was a smart man): he says "being good is hard"; for me, a man's good enough as long as he's not too lawless, and has the sense of right that does cities good; a solid guy. I won't find fault with a man like that. After all, isn't there a limitless supply of fools? The way I see it, if there's no great shame in it, all's fair».

${ }^{26}$ As Giuliano says (1992: 143), ancient Greek literature offers several evidences of a semantic distinction between "being" and "becoming". By way of example, he reports a passage of Aristophanes' Frogs (vv. 1187ff.) in which the tragic poet Aeschylus reproaches Euripides for

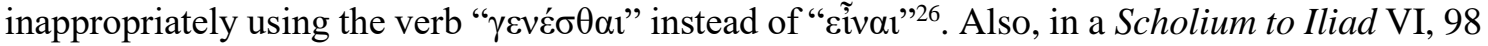
it is written that Homer, in having Helenus claim that Diomedes became the mightiest of the Acheans, was right in using the verb " $\gamma \varepsilon v \varepsilon \varepsilon \sigma \theta \alpha$ " instead of " $\varepsilon \tilde{i} v \alpha l$ "26. As Giuliano explains (1992: 143), scholars like Woodbury (1953: 55, footnote 44) and Parry (1965: 307) have hypothesized that the verb " $\gamma \varepsilon v \varepsilon \dot{\sigma} \sigma \theta \alpha$ " was employed by Greek poets to denote the active display of virtue throughout difficulties, mostly in the military sphere) ${ }^{26}$, unlike "है $\mu \mu \varepsilon v \alpha \iota "$ which would denote a static possession of virtue as well as an "unactualized" disposition. It ought to be noted, however,
} 
Journal of Ancient Philosophy ISSN 1981-9471 - FFLCH/USP www.revistas.usp.br/filosofiaantiga
J. anc. philos. (Engl. ed.), São Paulo, v.13, n.2. p. 01-34, 2019.

DOI: http://dx.doi.org/10.11606/issn.1981-9471.v13i2p01-34

and the possibility that Simonides himself might have appealed to that distinction so as to stress two different aspects of goodness, namely achievement and preservation of $\mathrm{it}^{27}$. If that is the case, the Platonic Socrates might have been right in (unironically) detecting

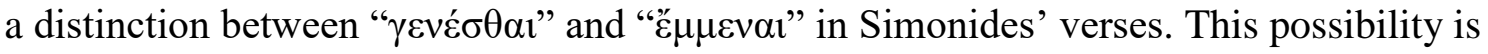
suggested by the fact that, aiming to interpret and even to rehabilitate ${ }^{28}$ Simonides, he resorts to the linguistic skills of Prodicus, a well-known expert in terminological analysis who, albeit being generally ranked among the most illustrious representatives of the sophistic movement, seems to be treated by Socrates himself with the respect typically due and the credibility given to friends. ${ }^{29}$ In the second place, nowhere in the dialogue

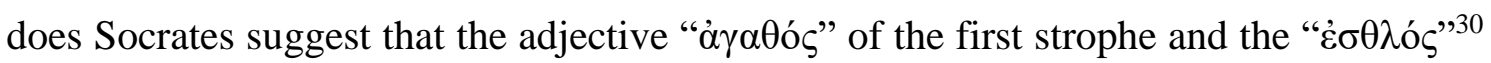
of the second express two different forms of goodness - not to mention the fact that the adjective " $\varepsilon \theta \theta \lambda$ ó $\varsigma$ " is generally employed in lyric poetry to indicate a supremely high virtue rather than an imperfect, less demanding degree of excellence. It is generally agreed that, by the end of the sixth century b.C., the word " $\dot{\varepsilon} \sigma \theta \lambda$ ó $\varsigma$ " had become a political label assumed by aristocrats (especially by aristocratic poets such as Theognis and Pindar) in their struggle against the populace - more specifically, against those who, in the attempt to overthrow aristocratic leaders, considered themselves "excellent" simply on the basis of possession of wealth and political offices. ${ }^{31}$ At the time of Simonides, then, the adjective " $\dot{\varepsilon} \sigma \theta \lambda o ́ \varsigma$ ” (similarly to “ $\alpha \dot{\gamma} \alpha \theta$ ó $\varsigma$ ”) had ended up denoting a virtue based on moral

that nothing hinders " $\varepsilon \mu \mu \varepsilon v \alpha \iota$ " from meaning in some contexts " $\gamma \varepsilon v \varepsilon \varepsilon \sigma \theta \alpha \imath$ ". See for instance line 15 of the Simonidean poem, which says that it is not possible for a man not to turn bad (ž $\mu \mu \varepsilon v \alpha$ ) whenever intractable disasters occur.

${ }^{27}$ See Woodbury 1953: 150; cf. Frede 1986: 741. For a detailed list of scholars who believe that Simonides is really interested in establishing a difference between "being" and "becoming" (although grounding that difference in assumptions different from from the ones implied by the Platonic Socrates), see Giuliano 1992: 141, footnote 139.

${ }^{28}$ As Socrates himself admits at Prot. 340a7, the reading he proposes is an $\dot{\varepsilon} \pi \alpha v o ́ \rho \theta \omega \mu \alpha$, that is to say, a "correction" of Simonides' views. The word "غ̇ं $\alpha$ ó $\rho \theta \omega \mu \alpha$ " is also used at Prot. 340d6, when he criticises Socrates for saying that his correction of Simonides implies that virtue is an easy thing to possess.

${ }^{29}$ See for instance Plato, Hippias Major 282c, where Socrates calls Prodicus his "friend"

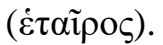

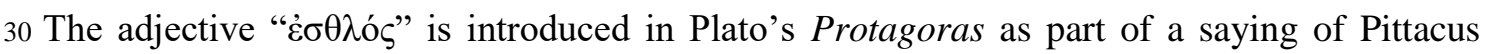
(340c5; cf. 344d6, and 344e3).

${ }^{31}$ See Bowra (1934: 233). 
Journal of Ancient Philosophy ISSN 1981-9471 - FFLCH/USP www.revistas.usp.br/filosofiaantiga
J. anc. philos. (Engl. ed.), São Paulo, v.13, n.2. p. 01-34, 2019.

DOI: http://dx.doi.org/10.11606/issn.1981-9471.v13i2p01-34

desert. ${ }^{32}$ Therefore, there is no reason to suppose that Plato does not consider " $\alpha \gamma \alpha \theta$ ó $\varsigma$ " and " $\varepsilon \sigma \theta \lambda o ́ \varsigma$ " to be interchangeable, even more so if we consider that the real distinction which Simonides means to emphasize in the poem is the one between a perfectly good

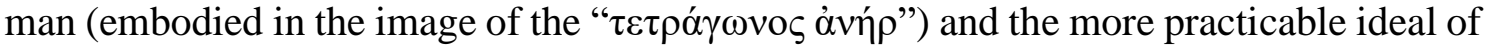

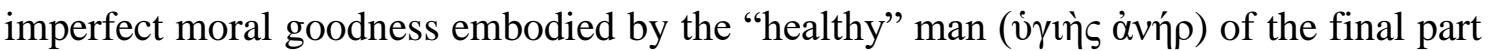
of the poem. Indeed, there is no strong evidence in the poem which might prompt us to maintain that already in the second strophe Simonides is foreshadowing the ideal of "moral health" worked out in the last strophe. The interpretation I support is the following: Simonides believes that perfect virtue is difficult, but not impossible to achieve. What is truly impossible, instead, is to preserve a stable, perfect virtue whenever a severely bad luck befalls a virtuous man. It is recognition of this fact which leads the poet to show appreciation for a less demanding ideal, one the attainment of which does not present the same degree of difficulty and implies an inferior amount of vain efforts.

\section{The tetragōnos man}

The idea of a supremely high virtue is vividly emphasized through the metaphorical ${ }^{33}$ image of the man " $\tau \varepsilon \tau \rho \alpha ́ \gamma \omega v o s$ in hands and feet" and "in mind" (see the

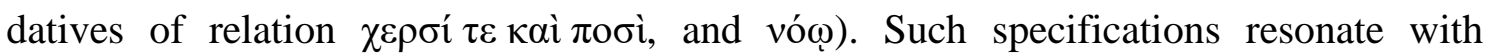
conventional ideas and images (visual as well as literary) well-known in his time. The combination of the excellences of hands and feet, for instance, indicates in Pindar the featuring trait of either victorious athletes (Pyth. x. 23,

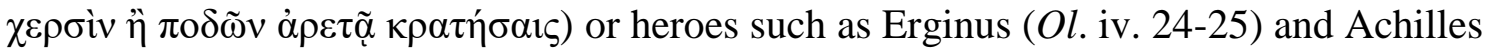
(Isthm. viii. 37). Also, the combination of "head" and "hand" appears in Pindar's descriptions of ideal manhood, which is embodied by men like Aiakos (Nem. viii. 8) ${ }^{34}$, as well as in Timocreon, who, speaks of an unnamed man (possibly Themistocles) outshining for excellence in hands and mind. ${ }^{35}$ This conjunction of talents underpins the

\footnotetext{
${ }^{32}$ See Wilamowitz-Moellendorf 1913: 159-191, Woodbury 1953: 152, and Donlan 1969: 74.

${ }^{33}$ Aristotle himself says that the image of the four-square man is metaphorical in Rhet. III, $11.1411 \mathrm{~b} 27$.

${ }^{34}$ See Bowra 1934: 231-232.

${ }^{35}$ PMG 727; Plutarch, Life of Themistocles 21; Bowra 1934: 231. Goold (Goold, George P. Greek Lyric, Vol. IV (Harvard University Press 1992), p. 85) reports the content of Sud. T 625 (iv 558
} 
Journal of Ancient Philosophy ISSN 1981-9471 - FFLCH/USP www.revistas.usp.br/filosofiaantiga
J. anc. philos. (Engl. ed.), São Paulo, v.13, n.2. p. 01-34, 2019.

DOI: http://dx.doi.org/10.11606/issn.1981-9471.v13i2p01-34

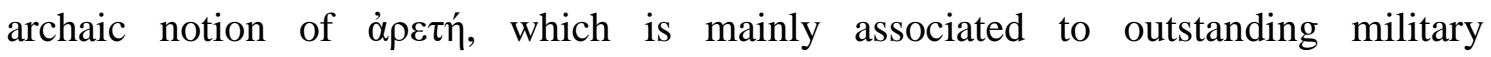
performances. $^{36}$

Noticeably, Simonides does not make any special reference to warlike virtue in the Ode to Scopas. This appears reasonable if we assume that his goal is to sketch out a comparison between the image of the supremely virtuous man and the more accessible (and therefore practicably recommendable) one of the healthy man, who is simply respectful of laws and refrains from harming people. In other words, the distinction between the two forms of goodness will be plausibly established in relation to a shared ground for assessment, not in the light of respectively different fields of action, such as a military and a properly "civic" one. In that case, the distinction at stake could simply refer to different levels of ethical perfection supposedly attainable in a given (and the same) situation. Simonides' image of the $\tau \varepsilon \tau \rho \alpha ́ \gamma \omega v o \varsigma$ man seems to indicate an all-embracing virtue, one which extends over and above mere courage in the battlefield and involves the capacity to display various forms of goodness in a wide variety of circumstances. Although Simonides does not straightforwardly explain the meaning of the adjective

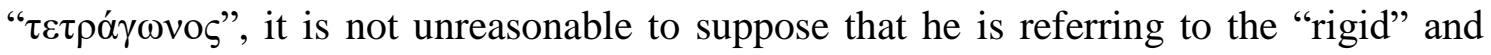
"incorruptible" nature of those who possess a stable disposition of character, especially with regard to their capacity to resist difficulties in a variety of contingent circumstances. This is for instance how Aristotle employs the same adjective to qualify the good man in absolute in the Nicomachean Ethics. As he says in NE I, 10.1100b19-22, a virtuous man will engage in action and contemplation in accordance with virtue and

will bear changes of fortunes in the fairest manner ( $\kappa \alpha \dot{\lambda} \lambda \lambda 1 \sigma \tau \alpha)$ and quite suitably in every regard ( $\pi \dot{\alpha} v \tau \eta\rceil \alpha \dot{\alpha} v \tau \omega \varsigma \dot{\varepsilon} \mu \mu \varepsilon \lambda \tilde{\omega} \varsigma)$ insofar as he is truly good $(\dot{\alpha} \lambda \eta \theta \tilde{\omega} \varsigma \dot{\alpha} \gamma \alpha \theta$ ó $)$ and square without flaw $(\tau \varepsilon \tau \rho \alpha ́ \gamma \omega v o \varsigma) .{ }^{37}$

We should not exclude that, just like the Aristotelian virtuous man, who on various occasions is deemed to be a measure and a criterion of evaluation of perfect human

Adler). As we learn from it, Timocreon, was a Rhodian and also a playwright of the Old Comedy: $\ll[\mathrm{H}] \mathrm{e}$ was at loggerheads with Simonides, the lyric poet, and with Themistocles the Athenian, against whom he composed a poem of censure in lyric metre. He wrote a comedy on the same Themistocles and the lyric poet Simonides in addition to other words».

${ }^{36}$ Cf. Vegetti, Mario. L'etica degli antichi (Laterza 1989), ch. 2.

${ }^{37}$ I adopt Johnston and Mulroy's translation of the passage (2004). 
Journal of Ancient Philosophy ISSN 1981-9471 - FFLCH/USP www.revistas.usp.br/filosofiaantiga
J. anc. philos. (Engl. ed.), São Paulo, v.13, n.2. p. 01-34, 2019. DOI: http://dx.doi.org/10.11606/issn.1981-9471.v13i2p01-34

agency $^{38}$, the Simonidean $\tau \varepsilon \tau \rho \alpha ́ \gamma \omega v o \varsigma$ man turns out to be a regulative model for excellent behaviour. As Johnston and Mulroy have for instance suggested, Simonides might have been inspired by the sphere of visual arts and, more specifically, by the world of archaic sculpture. ${ }^{39}$ The authors explain that tetragonal is for instance the shape of the grids employed by sculptors for the moulding of individual works, as well as the works themselves which through the grids get shaped. Surprisingly, Johnston and Mulroy identify the tetragonal grids as symbols for a model of action foreshadowing imperfect goodness, given that such grids were commonly used for the creation of herms - statues lacking limbs and generally symbolizing democratic power. ${ }^{40}$ In my opinion, admitting that Johnston and Mulroy are right in proposing that Simonides was really influenced by the sphere of sculpture (and I believe they might be right), it is perhaps more reasonable to suppose that the tetragonal grids evoke exclusively the idea of perfect goodness, insofar as the $\tau \varepsilon \tau \rho \alpha ́ \gamma \omega v$ o man excludes the idea of imperfection and is starkly different from the man who is simply "healthy", but not wicked and lawless.

In this light, it would be legitimate to use the phrase "truly virtuous" only by reference to the level of moral goodness displayed by the $\tau \varepsilon \tau \rho \alpha ́ \gamma \omega v o \varsigma$ man. This, of

\footnotetext{
${ }^{38}$ See for instance Nicomachean Ethics III, 4.1113a32-34, where Aristotle explains that the good person (o $\sigma \pi 0 v \delta \alpha i \tau)$ ) behaves differently from the the masses, who judge as "good" something which is not, mostly because it is pleasant and it looks like a good: «The good person judges each case rightly, and in each case the truth is manifest to him. For each state has its own conception of what is noble and pleasant, and one might say that the good person stands out a long way by seeing the truth in each case, being a sort of standard and measure of what is noble and pleasant». Cf. NE X, 5. 1176a21-23. Tr. Crisp, Roger, Aristotle. Nicomachean Ethics (Cambridge University Press 2000).

${ }^{39}$ See Johnston and Mulroy 2004, especially p. 6. The authors criticize those scholarly views (e.g. Smyth (1900), Bowra (1934), and Parry (1965)) contending that the Simonidean $\tau \varepsilon \tau \rho \alpha ́ \gamma \omega v o \varsigma$ man evokes the nature and function of the Pythagorean $\tau \varepsilon \tau \rho \alpha \kappa \tau$ ć, i.e. the geometrical representation of the number 'four', being a triangle made of ten points arranged in four rows, which played a central role in the secret worship of the Pythagoreans. Bowra, in particular (1934: 232), quotes the view reported by the Byzantine philosopher Proclus (412-485 AD), who in his comment on Euclides' Elements (Ad Eucl. Elem. $48 \mathrm{G}$ ) claims that the ancient Pythagorean notion of the

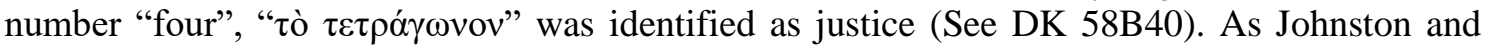
Mulroy suggest, a problem that this reading elicits is that there is no evidence for the dissemination of the details of Pythagorean numerological doctrines at such an early date, especially considering that the first extant use of the term " $\tau \varepsilon \tau \rho \alpha \kappa \tau v ́ s$ " occurs only in the writings of the Pythagorean Philolaus. This would suggest that Simonides is highly unlikely to have been familiar with that doctrine (cf. Cornford, Francis M. (1974). Mysticism and Science in the Pythagorean Tradition. In Mourelatos, Alexander P.D., ed. by. The Pre-Socratics: A Collection of Critical Essays (Princeton University Press 1974), pp. 135-160: 140, 148).
}

${ }^{40}$ See Johnston and Mulroy 2004: 6-8. 
Journal of Ancient Philosophy ISSN 1981-9471 - FFLCH/USP www.revistas.usp.br/filosofiaantiga
J. anc. philos. (Engl. ed.), São Paulo, v.13, n.2. p. 01-34, 2019.

DOI: http://dx.doi.org/10.11606/issn.1981-9471.v13i2p01-34

course, would not rule out the existence of people who, although falling short of perfection, can be classified as "simply good" and "healthy". Healthy people, indeed, fail to be regarded as authentically virtuous, but it is not for this reason that they ought to be considered either vicious or "by-no-means-good". If the adverb "truly" in verse 1 of the poem is to be attached to the adjective "virtuous", it would indeed contribute to demarcate highest goodness from the one possessed by the morally imperfect person. However, we should not forget that the issue as to what "truly" qualifies" is a matter of debate. The position of "truly" in verse 1 is the following:

[T] o become a good man truly is difficult, in hands and feet and mind square, fashioned without fault .

On Socrates' reading, Simonides employs "truly" as a qualification of the adjective "difficult", not of the adjective "good". As he explains by way of a reductio ad absurdum, if Simonides meant to say that "becoming a truly good man" is difficult, the adverb "truly" would become redundant, in that "good" means already "authentically good" (without the need of any further qualification). The Socratic reading appears to be premised on the idea that, in order to be reckoned as "good", a man or a thing must be alredy "truly" as such. As it seems to me, the Socratic interpretation of verse is plainly ironic. In other words, the Platonic Socrates, although aware of the poet's real intentions, would willingly propose an incorrect reading - either to mock other exegetes of his time, who deliberately deceive people, or rather to depart from literal exegesis and take an opportunity for expressing a distinctively Socratic(-Platonic) view: namely, the idea that we can speak of goodness only with reference to the highest one. Whatever the reasons, it is evident that he would not be interested in conveying Simonides' original message.

While Socrates denies that Simonides means to place emphasis on the idea of a "truly virtuous man", Aristotle does not. In the already mentioned passage at Nicomachean Ethics NE I, 10.1100b19-22, Aristotle resorts to Simonides in support of his personal view of the virtuous man by explicitly referring to the one who is "truly good" ( $\dot{\alpha} \lambda \eta \theta \tilde{\omega} \varsigma \dot{\alpha} \gamma \alpha \theta$ ó $\varsigma)$. The fact remains, however, that Simonides, unlike Aristotle, does not take the $\dot{\alpha} \lambda \eta \theta \tilde{\omega} \varsigma \dot{\alpha} \gamma \alpha \theta$ ó $\varsigma$ to express the one and only way of being virtuous. As I shall try to argue in the pages that follow, Socrates makes use of Simonides to show that even a minimum level of moral goodness can be included in the idea of virtue, and that it 
Journal of Ancient Philosophy ISSN 1981-9471 - FFLCH/USP www.revistas.usp.br/filosofiaantiga
J. anc. philos. (Engl. ed.), São Paulo, v.13, n.2. p. 01-34, 2019.

DOI: http://dx.doi.org/10.11606/issn.1981-9471.v13i2p01-34

is precisely on the threshold between decency and badness that the idea of a "healthy", "not too wicked nor lawfulness" man hinges.

At any rate, neither form of goodness is necessarily stable. Simonides acknowledges the possibility that unexpectedly bad events befall good persons, and he seems to place special emphasis on the precarious nature of perfect virtue, which is not immune to the strikes of an unmanageable bad luck (although even a "healthy" man could in principle become utterly bad ${ }^{41}$ ). In Prot. 344c3-4 Socrates quotes the following Simonidean verses:

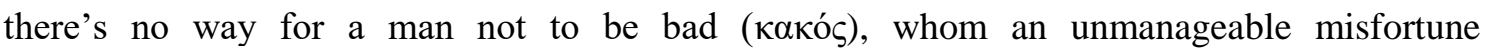

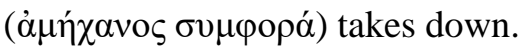

This is not necessarily to say that, at some point in life, a perfectly virtuous man must necessarily cope with a series of irresistibly negative events. ${ }^{42}$ Nevertheless, the poet brings to light the fact that, if a severely bad luck occurs, not even the $\tau \varepsilon \tau \rho \alpha ́ \gamma \omega v o \varsigma$ man can preserve his moral and intellectual resources. A reasonable implication of Simonides' use of the adjective " $\alpha \mu \eta \eta \chi \chi \alpha \nu \varsigma \varsigma$ " (meaning "irresistible" or "against which nothing can be done") is that only that sort of bad luck - and not a series of non-extraordinarily bad events - has the power to strike the $\tau \varepsilon \tau \rho \alpha ́ \gamma \omega v o \varsigma$ down and deprive him of his resources. It is not a case that Socrates speaks of the skilled person (in technical crafts as well as in

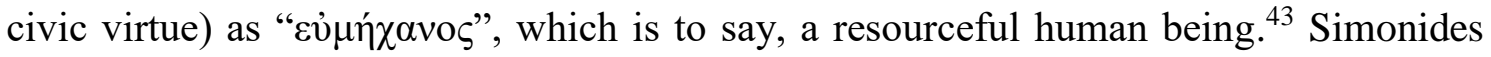
does not clarify whether a perfect man, once having turned bad due to irresistible bad luck, can possibly restore his original virtue. His main concern is rather the fact that not even perfect excellence is by itself permanent.

${ }^{41}$ See Coby, Patrick. Socrates and the Sophistic Enlightenment. A Commentary on Plato's Protagoras (Associated University Presses 1987), p. 118. Following the example of doctors, Socrates' reads Simonides as entailing that «only who are good doctors, and better still good doctors, can become bad» (my italics).

${ }^{42}$ Cf. Denyer 2008: 161 . As the commentator explains, Simonides is aware that some perfectly good men are lucky enough to live out their lives without meeting unmanageable disasters, and he refers to the sheer possibility that such men are striken by them.

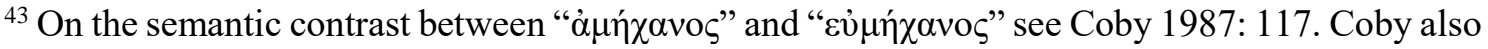
explains that $\alpha \mu \eta \chi \alpha v^{\prime} \alpha$ is not simply inability to be resisted, but also lack of the needed means to resist: «Socrates tacitly identifies evil with resourcelessness and being good with resourcefulness». In the passage of the Protagoras under examination, resourcefulness is

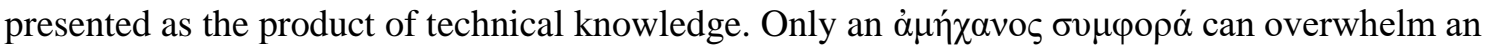

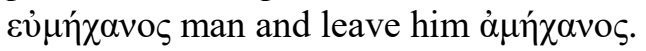


Journal of Ancient Philosophy ISSN 1981-9471 - FFLCH/USP www.revistas.usp.br/filosofiaantiga
J. anc. philos. (Engl. ed.), São Paulo, v.13, n.2. p. 01-34, 2019.

DOI: http://dx.doi.org/10.11606/issn.1981-9471.v13i2p01-34

\section{The imperfectly good man. A preliminary outline}

In the first two strophes of the poem, by placing emphasis on the difficulty in achieving and the impossibility of preserving perfect virtue in case of an extremely bad luck, Simonides sets the basis for the endorsement of a form of virtue which is less demanding in quality than the one possessed by the perfect man. Praising an imperfect virtue is probably compatible with the idea that the production of lyric works was specifically tailored to the needs of individual committees (usually members of aristocratic or, more generally, political élites). It ought not to be forgotten that the poem under examination was addressed to Scopas, a man outstanding in power and wealth, not in virtue. It is highly likely, then, that Simonides' references to a modest degree of virtue are ultimately meant to place bring to the fore the real qualities that Scopas is held to possess, rather than pretending to offer lessons on perfect morality. On the one hand, Simonides does not mean to present a relatively low degree of virtue as an objectively preferable pattern of human conduct over perfect virtue. It is not perhaps a case that he introduces the positive aspect of an "imperfect virtue" by qualifying it as the object of his personal point of view. That is to say, if he were called to choose between pursuing perfect virtue (thus facing the difficulties and the risks entails by this pursuit) and living a more modest moral life, he would personally stay content with the benefits stemming from the less demanding option. The idea that Simonides is expressing just a subjective preference emerges in Protagoras 345c5-10,

[T]herefore not ever shall $I(\dot{\varepsilon} \gamma \omega \dot{~})^{44}$, searching for what cannot come into being,

toss a share of my life onto an empty impractical hope, [the hope of] an entirely blameless man, among all of us who reap the solidly founded earth.

The verses above suggest that Simonides does not by any means want to "impose" imperfect virtue as a pattern of ethical conduct. The employment of the I-form permeates the rest of his praise of the moderately virtuous person:

\footnotetext{
${ }^{44}$ All the italics in these verses are mine.
} 
Journal of Ancient Philosophy ISSN 1981-9471 - FFLCH/USP www.revistas.usp.br/filosofiaantiga
J. anc. philos. (Engl. ed.), São Paulo, v.13, n.2. p. 01-34, 2019.

DOI: http://dx.doi.org/10.11606/issn.1981-9471.v13i2p01-34

But $I$ praise and love all, whoever willingly does nothing shameful; and not even do the gods fight with necessity.

I am not a lover of blame. For me it is fitting that a man not be wicked nor completely lawless, [a man] understanding justice [a thing] useful to the state, a healthy man; and him $I$

shall not blame; you see, [there are] generations

of numberless fools;

all things are fair, [the things] with which

ugly things are not mixed.

Looking at the strophe above, we may note a glaring omission in Simonides' characterisation of the imperfectly good man: the fact that a particularly bad luck might jeopardise not simply the preservation of the highest virtue (whatever this virtue might be), but even the maintenance of less perfect virtue (not to mention the idea that bad luck might prevent the acquisition of both perfect and imperfect virtue). Although he does not make this point explicit, Simonides is probably well aware that even a modest, simply "decent" morality is amenable to the same strikes of bad luck which might befall a perfectly virtuous person. A possible argument that he might have advanced in regard of this thought is that, since bad luck has the power to destroy all prospects of stable goodness, it is perhaps worth striving for the kind of goodness which requires less efforts. This is not, however, what he says in this strophe. We can hypothesize that, by way of a somehow "sophistical" move, he passes off in silence some supposedly negative implications of imperfect moral goodness, having preferred to focus in the previous strophe on the disadvantages experienced by perfectly virtuous people. Given the supposed aim of the poem, he does not seem willing to offer a fair characterisation of the positives and negatives of imperfect moral goodness.

Whether or not Simonides' argumentative strategies betray sophistic attitudes, giving up the search for a blameless person in absolute marks a shift of interest towards the imperfectly good man. For in the already mentioned lines we read

[B]ut $I$ praise and love all, whoever willingly does nothing ugly; and not even do the gods fight with necessity. I am not a lover of blame. 
Journal of Ancient Philosophy ISSN 1981-9471 - FFLCH/USP www.revistas.usp.br/filosofiaantiga
J. anc. philos. (Engl. ed.), São Paulo, v.13, n.2. p. 01-34, 2019.

DOI: http://dx.doi.org/10.11606/issn.1981-9471.v13i2p01-34

By claiming "I am not a lover of blame", the poet implicitly makes room for a more inclusive view of moral acceptability, namely one which extends beyond the nature and the behaviour of perfectly virtuous men. As we see in line 23-24, by introducing the issue of necessity of absolute irreversibility ("not even the gods fight with necessity"), Simonides reaffirms in a stronger way the idea (already expressed at vv 8-13) that human virtue (not even the highest one) cannot survive against profoundly adverse conditions. This might be a good reason to re-evaluate imperfect moral goodness and avoid blaming those embodying such a modest ideal. It is worth noticing that Simonides does not characterize the figure of the imperfectly good man by situating it somewhere in between perfect goodness and utter wickedness. The conceptual image of such a man is outlined exclusively with reference to the negative ideal of wickedness:

For me it is fitting that a man not be wicked nor completely lawless, [a man] ö $\gamma \alpha v \dot{\alpha} \pi \alpha ́ \lambda \alpha \mu \nu o \varsigma$.

As I have already pointed out at footnote 5 of this essay, Arieti and Barrus (on whose translation I have relied so far) translate ơ $\gamma \alpha v \dot{\alpha} \pi \alpha ́ \lambda \alpha \mu v o \varsigma$ as “too inept”. Generally speaking, ineptitude might indicate a lack of moral resources that would make a person inadequate to act well and be accounted as good at some level. To say that a person is not too inept might mean that the same person possesses either a minimum or an intermediate level of moral goodness. As is suggested in the Liddell-Scott-Jones Greek-English Lexicon (1996), however, the adjective $\alpha \dot{\alpha} \alpha \dot{\lambda} \alpha \mu \nu \varsigma_{\varsigma}$ is generally employed in archaic lyric poetry to denote either a lawless person or a lawless behaviour. If Simonides meant to use $\dot{\alpha} \pi \alpha \dot{\lambda} \alpha \mu \nu$ os in this traditional sense, the concept of lawlessness in his poem would perhaps contribute to emphasizing the idea that imperfect moral goodness, contrary to total absence of respect for the laws, represents a minimum level of moral decency. it seems to me, it is precisely on this minimum level of moral decency and acceptability that Simonides aims to put the focus when he describes imperfect moral goodness as a more practicable ideal than perfect virtue in absolute. Just to mention a possible reason reason why this ought to be so, in verses 31-32 Simonides claims that "beautiful"/"fine"

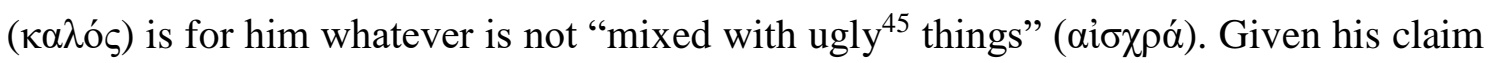
that he is not a lover of blame, Simonides cannot consider "ugly" any imperfect behaviour

\footnotetext{
${ }^{45}$ I believe that the use the translation "ugly" instead of "shameful" here is particularly fitting in the light of Simonides' aversion toward blame.
} 
Journal of Ancient Philosophy ISSN 1981-9471 - FFLCH/USP www.revistas.usp.br/filosofiaantiga
J. anc. philos. (Engl. ed.), São Paulo, v.13, n.2. p. 01-34, 2019.

DOI: http://dx.doi.org/10.11606/issn.1981-9471.v13i2p01-34

that can be qualified as close to moral perfection, just as he cannot consider "beautiful" or "fair" only those things that express perfect goodness. The image of "beautiful things" as "things not mixed with ugly things" conveys not only a modest ideal of moral decency, but also one which marks a specific dividing line between "beautiful" and "ugly". As Simonides allows his readers to infer in his verses, those acts from which a good man in the imperfect sense refrains are the same that qualify a person as wicked and totally lawless. Utterly bad (and therefore justifiably blameable) are not those acts which fail at displaying the full-fledged moral potentialities of the $\tau \varepsilon \tau \rho \alpha ́ \gamma \omega v o \varsigma$ man, but only those deeds issuing in neglect of justice and the infringement of the utility of the political community, as the verses below suggest:

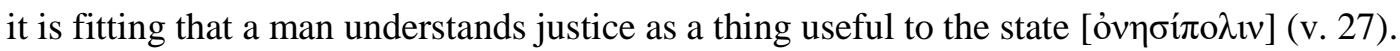

By 'wicked' and 'lawless' Simonides seems to indicate a person who fails to understand that justice represents a useful resource for the wellbeing of the polis. By using

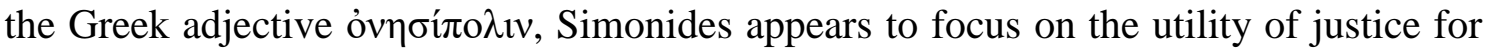
the polis as a whole, not on the utility of each member of a given community by itself. Simonides' reader might be allowed to suppose that the justice useful for the polis might reside in those laws (either written or unwritten) promoting order. Presumably, it is mainly by way of laws and customs that a city successfully manages to endorse and preserve the grounds for a harmonious coexistence between its members. Various forms of unlawful behaviour may bring one to commit injustice against one's fellow/s and, as a consequence, to undermine the strength of those ethical principles out of which which a certain community derives its identity (which is to say, its constitutive aims and political strategies). Regardless of the possible ways in which the preservation of common utility occurs (either by written or by unwritten laws or both), inflicting harm on a certain person might by extension undermine the credibility (or simply the good functioning) of a community which does not take pains of punishing injustice.

As it is plausible to assume, abstaining from that sort of disrespectful behaviour is precisely the attitude that marks a threshold of decency and moral acceptability. Abstention, then, would constitute a minimal form of moral goodness, that is, one below which no human being could be considered morally good. Equally plausible, in my opinion, is the view that the mental state out of which the imperfectly virtuous man 
Journal of Ancient Philosophy ISSN 1981-9471 - FFLCH/USP www.revistas.usp.br/filosofiaantiga
J. anc. philos. (Engl. ed.), São Paulo, v.13, n.2. p. 01-34, 2019.

DOI: http://dx.doi.org/10.11606/issn.1981-9471.v13i2p01-34

refuses to perform ugly actions is a distinctive sense of shame, one which, by incorporating thoughts about what is to be counted as "morally good behaviour", fear of reprobation ${ }^{46}$, and a sense of one's own value as a vulnerable good to protect against bad reputation, makes the prospect of committing injustice deeply undesirable. ${ }^{47} \mathrm{~A}$ similar sense of shame might be the one evoked by the concept of $\alpha i \delta \omega$, which in the Protagoras the homonymous sophist introduces within the framework of his well-known myth on the origin and development of human beings and their distinctive natural faculties (see

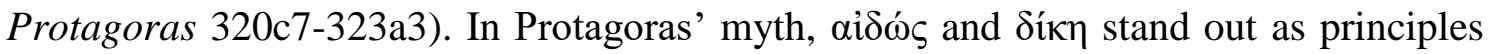
which, besides their power to avoid irremediable war and conflict, establish order and steady bonds of friendship among human fellows (see Protagoras 322c2-4). The words

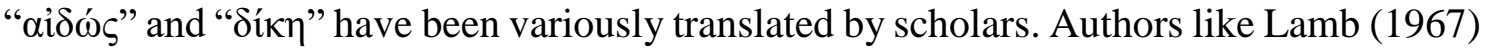

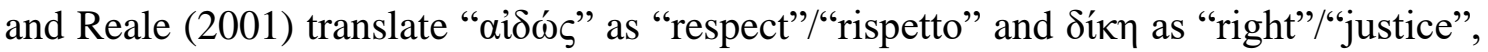

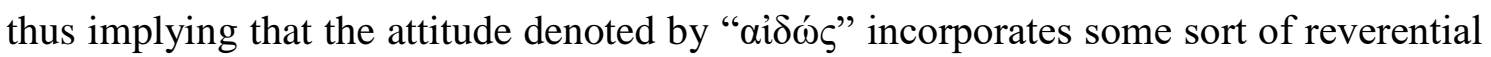
recognition (or even reverential fear ${ }^{48}$ ) of the worth or the authority of the subject(s) before which one feels it (either human beings or the laws of the city). Protagoras does

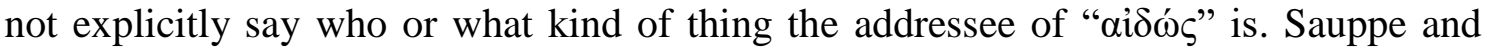

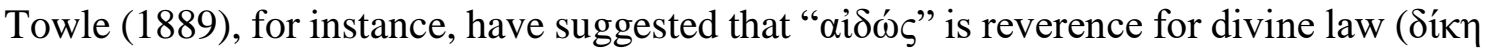

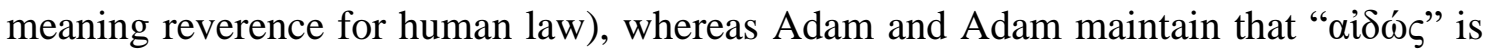
specifically concerned with fear of the censure that might stem by one's human fellows. ${ }^{49}$

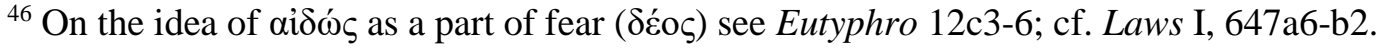

${ }^{47}$ For a comprehensive treatment of the notion of $\alpha i \delta \omega ́ s$ in ancient Greek literature and philosophy up to Aristotle's death see Cairns, Douglas. Aidōs: The Psychology and Ethics of Honour and Shame in Ancient Greek Literature, (Oxford University Press 1993). As Cairns explains in the

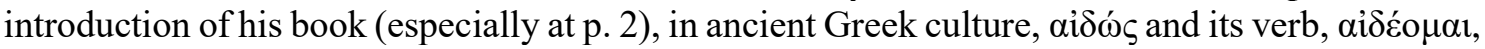
take on specific connotations, depending on the contexts in which these are employed. Generally

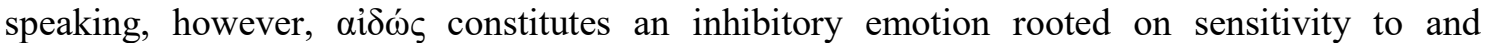
protectiveness of one's self-image. That emotion, being premised on recognition that one's selfimage is vulnerable in some way, would lead to virtuous behaviour and to forms of positive

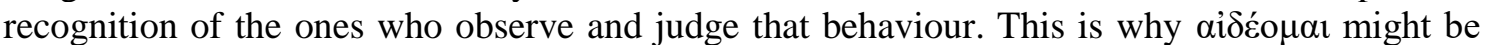
translated as "I feel ashamed" before someone but also and especially as "I respect" someone).

${ }^{48}$ Arieti and Barrus put a sense of what is 'legally just'.

${ }^{49}$ In support of this view, see the use of aidós in Homer, Iliad XV, 561, in which the Telamonian Aiax urges his fellow-soldiers to have shame of each other (presumably to refrain from the temptation of abandoning the battlefield), Hesiod (Works and Days, 192), who foresees an age of corruption in which neither shame nor reciprocal justice will exist, and Plato in Laws I, 647a1-c2

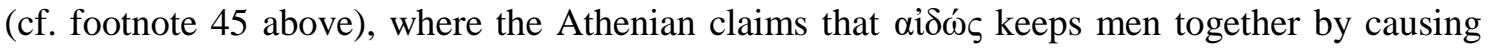
them to fear the possibility of censure by their fellows.
} 
Journal of Ancient Philosophy ISSN 1981-9471 - FFLCH/USP www.revistas.usp.br/filosofiaantiga
J. anc. philos. (Engl. ed.), São Paulo, v.13, n.2. p. 01-34, 2019.

DOI: http://dx.doi.org/10.11606/issn.1981-9471.v13i2p01-34

Like Adam and Adam, I believe that “ $\alpha i \delta \omega \varsigma$ " in Protagoras' myth involves mostly (if not

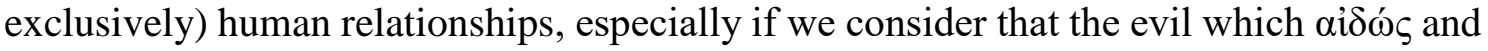

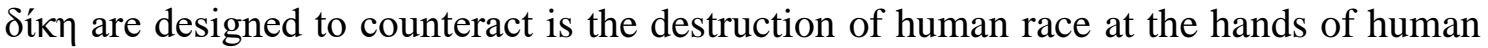
beings themselves. As it is suggested in the Protagorean myth, the risk of human race extinction persists even when human beings, by receiving the gift of fire by Prometheus (who stole it from Hephaestus), are given the opportunity to take part in the divine, and kinship to deity prompts them to believe in the gods and build altars and images of them (Prot. 322a3-6). As it seems, reverence for the gods does not prevent human beings from

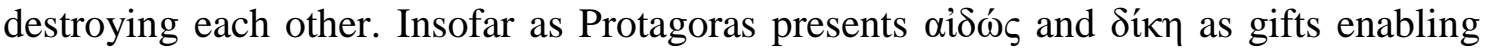
human beings to create order and stable bonds of friendships within political communities, these principles seem to address primarily cases of lack of respect and injustice between human beings, not cases of disrespect of human beings towards divine beings.

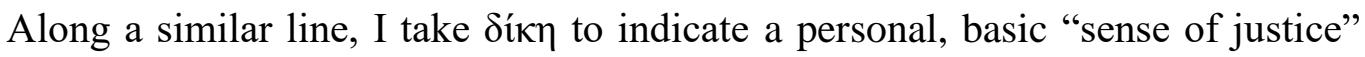
(and not an impersonal set of rules of behaviour), one by which people are inclined to

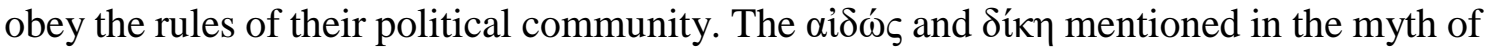
Protagoras are not to be identified with the sense of shame and respect for justice that prompts people to perform supererogatory deeds, given that Protagoras simply means to highlight their power to promote order and stability, as well as its capacity to ward off open conflict in human relationships. The kind of respect for others which cultivation of individual sense of shame fosters, then, is simply the one which persons owe to each other with a view to avoiding reciprocal harm and encourage human survival. It is precisely in virtue of this kind of respect that exercise of a basic level of virtuous inter-relational capacity within a certain community can be secured.

As Protagoras explains after narrating the myth, the Athenians are right in believing that each and every member of the political community owns some degree of

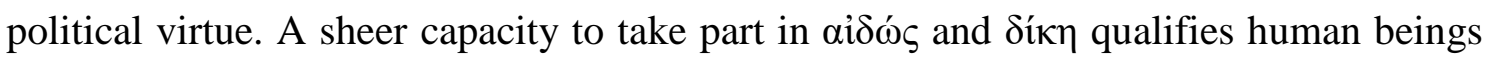
not only as distinctively human, but also as persons capable of acting according to the system of justice in force in the city and of giving advices on the management of political activity. Protagoras suggests that political virtue (and, as we might legitimately suppose, the individual sense of shame) can be trained by means of a targeted education. Although not every person receives the same education in the study of poetry, music and 
Journal of Ancient Philosophy ISSN 1981-9471 - FFLCH/USP www.revistas.usp.br/filosofiaantiga
J. anc. philos. (Engl. ed.), São Paulo, v.13, n.2. p. 01-34, 2019.

DOI: http://dx.doi.org/10.11606/issn.1981-9471.v13i2p01-34

gymnastics ${ }^{50}$, everyone is raised by a family whose members (father, mother, tutor, nurse) help him to rectify bad behaviour and to discern the just from the unjust. What is more, everyone is constrained by the city to live according to the laws established by wise lawgivers, and to accept those punishments which aim to rectify transgression of them. In the light of the mythical narration previously proposed, we might hypothesize that an equal access to shared resources for the acquisition of a sense of justice is what qualifies human beings as human. As Protagoras will explain after his myth in the attempt to show that political virtue is teacheable, different persons will achieve respectively different degrees of political virtue depending on their natural talents and the education received. ${ }^{51}$

If we are allowed to establish a correspondence between Protagoras' and Simonides' ideas on imperfect or incomplete virtue, we might hypothesize that untrained $\alpha i \delta \omega ́ \varsigma$ and $\delta i ́ \kappa \eta$, that is to say, the sense of shame and justice which are not necessarily employed as a springboard for higher moral and political achievements, mark a minimum degree of moral decency - the same which Simonides might supposedly work out and praise in his ode. A man who refrains from performing evil deeds can be praised insofar as he or she willingly chooses to avoid them. It is in this respect that Simonides might be right in claiming that

[B]ut $I$ praise and love all, whoever willingly does

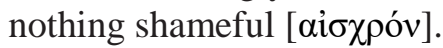

The idea of willingly refraining from performance of bad actions would exclude that minimal justice is an inertial, passive attitude, and justifies the idea that such a form of agency can be praised. On the other hand, it is worth noting that the Platonic Socrates denies that the adverb "willingly" is to be attached to "doing nothing shameful", and places the phrase "willingly" next to "praise". The underlying assumption of the Socratic

\footnotetext{
${ }^{50}$ As Protagoras explains at Prot. 326c2-5, the sons of wealthiest people begin school at an earlier age than the sons of poorer people, and are freed from it at the latest.

${ }^{51}$ See Prot. 324d2-326e4. The context in which Protagoras justifies his belief is a discussion concerning the teachability of virtue. To Socrates, who suggests that virtue is not teachable because, if it were so, virtuous politicians would never have vicious or incompetent sons in politics, Protagoras replies that this objection is misleading. On his view, failure of good politicians to teach political virtue would depend on the politicians' carelessness for the education of their sons, and not on a structural impossiblity to teach virtue. A high degree of political virtue could be acquired by anyone having talents and an appropriate education outside the family, independently of virtuous parents.
} 
Journal of Ancient Philosophy ISSN 1981-9471 - FFLCH/USP www.revistas.usp.br/filosofiaantiga
J. anc. philos. (Engl. ed.), São Paulo, v.13, n.2. p. 01-34, 2019. DOI: http://dx.doi.org/10.11606/issn.1981-9471.v13i2p01-34

exegesis is that, just as nobody does wrong knowingly ${ }^{52}$, nobody who refrains from bad behaviour would do it unwillingly. In which case, in the idea of a voluntary abstention from evil would appear pleonastic. The reading proposed by the Platonic Socrates does not seem to match the original meaning of Simonides' verses. Indeed, what the Socratic exegesis (if read at a surface level) fails to take into account is the fact that for some people to abstain from injustice is the object of painful efforts, and therefore requires a self-conscious commitment.

By way of such an exegetical move, Socrates directs the reader's attention to the possibility that Simonides (contrary to his real inclinations) may willingly force himself to accord praise on a lifestyle which is not his own, namely imperfect moral goodness, either to the effect of obtaining some material benefits from the addressee of the poem, Scopas, or simply with a view to achieving the glory that good poetical activity enables one to attain. This Socratic interpretation accords well with the view of a "mercenary Simonides" ${ }^{\circ 3}$, who sells himself and show lack of coherence between the values he praises in contingent situations (like the composition of a poem with purely encomiastic intentions) and the one he truly endorses in his life. However, it would be extremely unlikely for the poet to openly express purely encomiastic intentions towards the tyrant Scopas, and it is perhaps plausible to assume that this is precisely what Socrates himself believes. Therefore, he might deliberately misinterpret Simonides - perhaps in order to give a display of exegetic abilities disconnected to the truth, as many sophists do, or

\footnotetext{
${ }^{52}$ See Prot. 358c8-d5: «no one in fact willingly goes toward what's evil or toward what he thinks evil, nor, as is likely, is this [behavior] in human nature - to be willing to go to what one thinks is bad instead of good; and when one is constrained to choose one of two evils, no one will choose the greater [evil] when it is possible to choose the lesser».

${ }^{53}$ See for instance Plato, Hipparchus 228c2-3, where Socrates explains that Hipparchus induced Simonides to be in continual attendance upon him by high pay and valuable presents (cf. Barnstone 2010: 118: "Like Anakreon he was one of the poets invited to Athens by Hipparchus as part of the program of cultural enrichment inaugurated under the Peisistratid tyranny"). See also Aristophanes, Peace 695-701, where Tyrtaeus tells Hermes that Sophocles has turned into Simonides, having become so greedy that he would put to sea on a hurdle just to gain an obolus. Plutarch (Moralia. Saying of Kings and Commanders 9, Loeb ed.: 91.15e) (see Johnston and Mulroy 2004: 2), who claim that "Plutarch (Moralia 15e) preserves the tradition that Simonides dumbed his poetry down for the benefit of the whole family of the Skopads, who were relatively unsophisticated"). Also, as we learn from Aristotle, Rhet. II, 16.1391a9-12, he praised money more than wisdom: «Hence the answer of Simonides to the wife of Hiero concerning the wise and the rich, when she asked which was preferable, to be wise or to be rich. 'Rich,' he answered, 'for we see the wise spending their time at the doors of the rich'» (tr. Freese, in Freese, John H., ed. by and translated. Aristotle. Rhetoric (Harvard University Press 1926)).
} 
Journal of Ancient Philosophy ISSN 1981-9471 - FFLCH/USP www.revistas.usp.br/filosofiaantiga
J. anc. philos. (Engl. ed.), São Paulo, v.13, n.2. p. 01-34, 2019.

DOI: http://dx.doi.org/10.11606/issn.1981-9471.v13i2p01-34

possibly with a view to finding an opportunity to exhibit authentically Socratic assumptions on the involuntariness of evil, or even for both reasons.

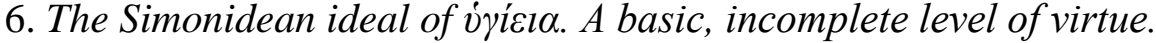

In verse 36 of the poem, the imperfectly good man is described as "healthy". 54 The idea of a healthy man seems to lend support to the poet's willingness to dismiss the absolutely perfect man as an exclusive paradigm of moral goodness. According to the documentary sources come down to us, Simonides is the first among the thinkers who attributed an ethical connotation to the notion of "health". Insofar as imperfect moral goodness is understood as a denial of wickedness, (moral) health will be viewed as "absence of (moral) sickness", rather than as the expression of a well-ordered, excellent disposition of character.

The sense of health as the metaphor for moral goodness appears in several textual sources of the 5th-4th century. The orator Isocrates, for instance, considers the "health of the soul" to be one of the the best and most desirable goods alongside health of the body

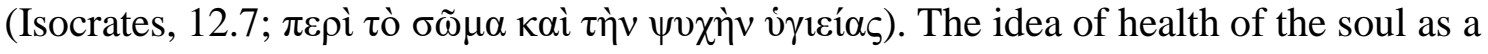
good worth pursuing (and not simply as a morally acceptable condition) appears also in the Platonic dialogues, where the notion at stake denotes a full-fledged good. In several of his dialogues, Plato resorts to the concept of physical health (ivíi $1 \alpha$ ) in support of his attempt to illustrate the human goodness at its fullest, as well as and the character of those agents who manage to instantiate it in their lives. To confirm the character of objective perfection of such a good, in several occasions health is presented as the product of a $\tau \dot{\varepsilon} \chi v \eta^{55}$, that is to say, of a true craft, which makes it different from a simple appearance of goodness. ${ }^{56}$ Plato appears interested in presenting health of the body as a condition of

\footnotetext{
${ }^{54}$ While Arieti and Barrus translate "v̛үińs" as "sound" at Protagoras 346c6, in appendix C they use the translation "healthy".

${ }^{55}$ See Plato, Meno 72d3-e2. Along a similar line, in the Euthydemus health is introduced as the "work", "product" or "effect" ("̌prov) of the medical craft (Euth. 291e4-5). See also the Gorgias on the note below.

${ }^{56}$ That possibility is fully explored in the Gorgias, where Socrates compares justice to a healthy condition of the soul. Here, health is described as the highest good of the medical craft

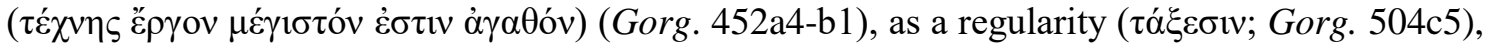

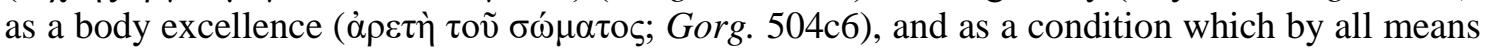
excludes disease (cfr. Gorg. 495e5-7, where Socrates explains that one cannot have at the same
} 
Journal of Ancient Philosophy ISSN 1981-9471 - FFLCH/USP www.revistas.usp.br/filosofiaantiga
J. anc. philos. (Engl. ed.), São Paulo, v.13, n.2. p. 01-34, 2019.

DOI: http://dx.doi.org/10.11606/issn.1981-9471.v13i2p01-34

order created by a technic-scientific knowledge. ${ }^{57}$ Most crucially, he establishes an analogy between health and justice in the soul (that is to say, an excellence, aretē). In the IV Book of the Republic, for instance, the Platonic Socrates claims that justice

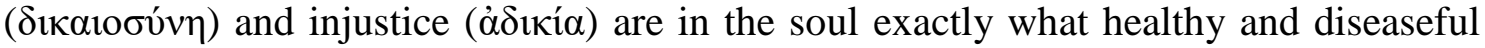

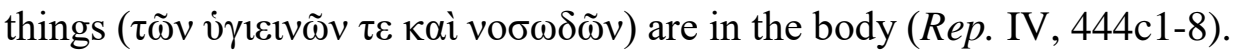

Just like health, justice represents a condition of goodness which can be achieved throughout an appropriate balancing of hierarchical relationships between qualitatively different elements. As the Platonic Socrates states in Rep. 444d3-11,

"But to produce health is to establish the elements in a body in the natural relation of dominating and being dominated ${ }^{1}$ by one another, while to cause disease is to bring it about that one rules or is ruled by the other contrary to nature".

"Yes, that is so."

"And is it not likewise the production of justice in the soul to establish its principles in the natural relation of controlling and being controlled by one another, while injustice is to cause the one to rule or be ruled by the other contrary to nature?"

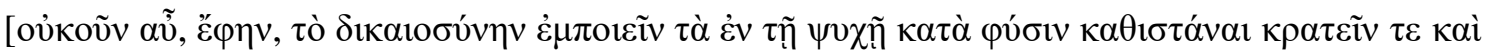

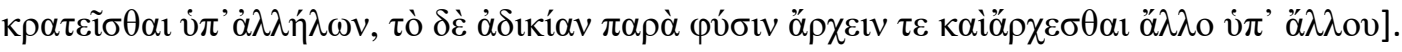

"Exactly so," he said.

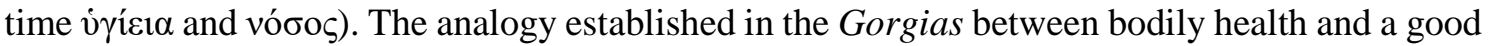
condition of the soul finds its sense within the framework of an attempt to illustrate the distinction between mere persuasion, being produced by rhetoric (a sheer flattery [ко $\lambda \alpha \kappa \varepsilon i ́ \alpha]$ disguised as craft), and authentic goodness and happiness, being the outcome of real justice (i.e. a real craft). Socrates proposes a classification of authentic crafts by comparing a broad expertise dealing with the soul, i.e. the political craft with a corresponding (unnamed) art dealing with bodily health. One of the fields into which politics can be subdivided is the art of legislation, which sets the conditions for good practice and the promotion of goodness in the soul. A second subdivision of

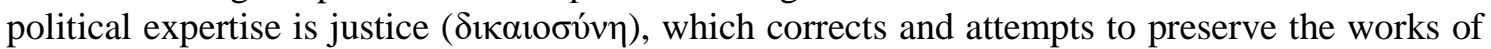
legislation. Correspondingly, the art dealing with bodily health can be subdivided into gymnastic, which endorses the discipline and good habits leading to bodily health, and medical craft ( $\dot{\eta}$

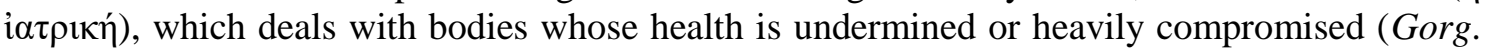

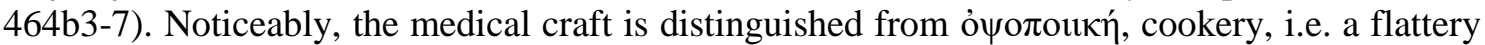
disguised as medicine (Gorg. 463b1-3). Correspondingly, the true good that the medical craft deals with, health, will differ from a condition of apparent goodness, grounded in pleasantness but not in the order of the body.

${ }^{57}$ As Socrates explains at Gorg. 503e1-504a5, the medical craft, which promotes authentic health,

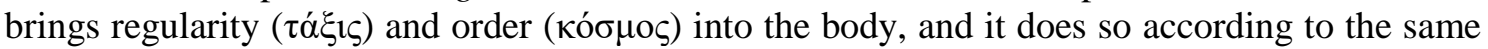
principle followed by an artist ( $\delta \eta \mu$ เov $\rho$ ós), who disposes everything according to a certain order, and causes one part to suit and to fit with another, to the effect of making the whole a regular and well-ordered work. 
Journal of Ancient Philosophy ISSN 1981-9471 - FFLCH/USP www.revistas.usp.br/filosofiaantiga
J. anc. philos. (Engl. ed.), São Paulo, v.13, n.2. p. 01-34, 2019.

DOI: http://dx.doi.org/10.11606/issn.1981-9471.v13i2p01-34

Interestingly enough, in the conclusive phase of the Socratic argument, the analogy between health and justice leaves room for a proper metaphor, through which virtue is taken to be not simply "similar" to health, but as "a form of health":

[V]irtue, then, as it seems, would be a kind of health and beauty and good condition of the soul, and vice would be disease, ugliness, and weakness."

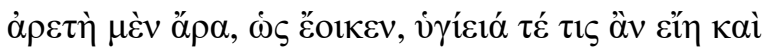

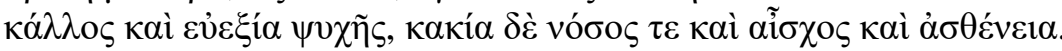

This is not the place for an extensive analysis of the notion of health and its role in Plato's elaboration of virtue and justice. For the aims of the present work, suffice it to establish that, for Plato, health is an optimal (either physical or moral) condition, and not simply one of "absence of sickness", as instead Simonides seems to regard it. Similarly, beauty in the passage above appears as a condition which, being associated to virtue and a good condition of the soul, cannot represent the qualifying trait of a minimal level of morality, as Simonides instead suggests when he claims that beautiful is simply whatever has no admixture of what is ugly. Unlike the Platonic Socrates, who contends that it is the presence of the beautiful that makes something beautiful, Simonides believes that beauty is the result of simple absence of evil (see the sentence "all things are fair, [the things] with which ugly things are not mixed" at vv. 31-32). ${ }^{58}$ It is therefore understandable why the Platonic Socrates, commenting on Simonides' view of beauty, points out that

$[\mathrm{H}] \mathrm{e}$ is not saying this as if he were saying that all things are white in which no black is mixed in - you see, this would be laughable for lots of reasons; but [he is saying] that he himself accepts the [things that are] in between [ $\tau \grave{\alpha} \mu \varepsilon \dot{\sigma} \sigma \alpha]$ so as not to blame [them] (Prot. 346d1-4).

From Socrates' point of view, the Simonidean "healthy" and "beautiful" things can ideally be situated in a space in-between perfect goodness and absolute evil. As the passage above implies, Socrates believes that the absence of sickness and ugliness cannot be used as definitory properties of goodness. If he did so, he would probably be ridiculed as the one who defined the white as the thing which contains no black. Indeed, as Socrates suggests, the essence of moral goodness cannot be identified with the absence of the things that goodness itself is not supposed to contain. What is more, in the light of perfect

\footnotetext{
${ }^{58}$ See Barrus and Arieti 2010, Appendix C, p. 121.
} 
Journal of Ancient Philosophy ISSN 1981-9471 - FFLCH/USP www.revistas.usp.br/filosofiaantiga
J. anc. philos. (Engl. ed.), São Paulo, v.13, n.2. p. 01-34, 2019.

DOI: http://dx.doi.org/10.11606/issn.1981-9471.v13i2p01-34

goodness, actions or persons lacking outstandingness ${ }^{59}$ would appear unworthy of praise. This is why the things "in-between" absolute virtue and absolute vice might be viewed not only as "intermediate" between goodness and evil, but also as the expression of a failure at achieving perfect goodness - a failure which, for Socrates, would justifiably rule out praise.

To my understanding, both approaches on virtue - namely the Simonidean and the Socratic ones - reflect a distinctively archaic way of presenting concepts, that is, one rooted in the the logic of "polarized opposites". ${ }^{60}$ In the case of Simonides, the image of the healthy person, being alien from vice and unlawfulness, can be outlined in opposition to the image of a person lacking a minimal level of respect for laws, one which does not refrain from accomplishing bad deeds. It is a similar opposition which allows Simonides to qualify the healthy person as properly virtuous, although not in the highest and most complete sense. By contrast, in Socrates' cricitism of Simonides, two oppositions seem to stand out: (1) the one between the absolutely good and the absolutely bad; (2) the one of mere absence of evil intentions and the absolutely good. ${ }^{61}$ If, in the light of opposition

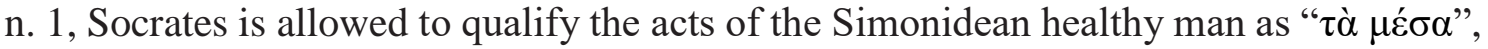
in the light of opposition n. 2 enables him to reckon minimal goodness as unworthy of praise. In other words, the Simonidean notion of "health", being compared by Socrates with absolute perfection, might evoke a condition of despicable "not-outstandingness".

As I believe, by so interpreting Simonides, the Platonic Socrates might also want to offer a clarification of a Simonidean positions that close to one which Protagoras expresses at Prot. 326d1-e4. One of these views consists in the idea that a person who, to Socrates' eyes, would appear as profoundly unjust might instead be viewed as good if compared to persons totally deprived of education and laws. Protagoras conveys this

\footnotetext{
${ }^{59}$ The negative connotation of "things that are in between" ( $\left.\tau \grave{\alpha} \mu \varepsilon \dot{\sigma} \sigma \alpha\right)$ is stressed in both Lamb's and Reale's translation.

${ }^{60}$ See the comment of Arieti and Barrus, p. 121: «the Greeks of Simonides' and Parmenides' generation, says Fränkel (Early Greek Poetry and Philosophy, p. 311), had a logic of polarized thought. Today we think of degrees of brightness; for the archaic Greeks, something moderately bright would have been a mixture of extreme opposites, so that a moderately bright day would have been composed of a mixture of total brightness and total darkness. By the same logic, if one quality is lacking, the opposite is wholly present. For Simonides, therefore, that which contains no mixture of the ugly is wholly beautiful. The idea, then, is this: it is not just the presence of the beautiful that makes someting fair, but the absence of evil».
}

${ }^{61}$ See Arieti and Barrus 2010, p. 121. 
Journal of Ancient Philosophy ISSN 1981-9471 - FFLCH/USP www.revistas.usp.br/filosofiaantiga
J. anc. philos. (Engl. ed.), São Paulo, v.13, n.2. p. 01-34, 2019.

DOI: http://dx.doi.org/10.11606/issn.1981-9471.v13i2p01-34

message by means of an analogy between a flute player and a man living in the polis. In the attempt to show that we ought not to expect the sons of virtuous politicians to become more virtuous in political matters than other young people, he says:

that the sons of good flute players would become good flute players any the more than [the sons of] inconsequential [flute players]? I think not, but anyone's son, having been born excellent-bynature in flute music, could become big and famous, and anyone's son who lacked natural [excellence] would be without fame. And often [the son of] a good flute player would prove to be an inconsequential [flute player] and the [son of an inconsequential flute player would prove] a good one. But however that might be, in fact, all [these] flute players would be adequate compared to laymen knowing nothing of the flute. And in this way, think even now that anyone reared among conventions and human beings who seems to you to be a very unjust human being is [nevertheless] himself just, even a craftsman of this, if he should need to be judged in comparison with human beings who have neither education nor law courts nor conventions nor any necessity continually necessitating anyone to take care for excellence, but are wild... (Prot. 327b3-d4).

As we see in the passage above, Protagoras not only justifies the idea that even persons lacking civic excellence can somehow be regarded as just, but he also refers to Socrates' assessment of that idea as an evaluation which appears based on a pure opinion. The sophist ${ }^{62}$, who is well known for his defense of what has been interpreted by Plato and Aristotle as an identity between truth and appearance ${ }^{63}$, opposes what "is" really just

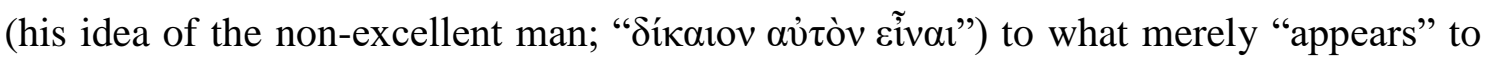

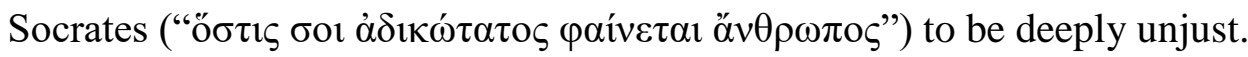

It is possible that, by introducing Simonides' poem and his defense of the healthy man, the Platonic Socrates means to provide a restatement of Protagoras' position on imperfect virtue and to give higher emphasis to a standpoint which he starkly opposes: namely, the idea that sheer respect of justice might be qualified as a form of virtuous behaviour. That point of view will be challenged by Socrates in the following pages of the Protagoras, where he will try to show that each virtue can be understood as a form of science (Prot. 360e7-361c2).

\footnotetext{
${ }^{62}$ At Prot. 348e3, Socrates says that Protagoras had publicly proclaimed himself to all the Greeks as a sophist, unlike others who make a secret of that art. At Prot. 319a1-8 Protagoras confirms to be a teacher of political science, and proclaims his commitment to making men good citizens.

${ }^{63}$ See for instance Aristotle, Metaph. K, 6.1062b12-19, who interprets the Protagorean pronouncement "Man is the measure" (óv $\theta \rho \omega \pi \circ \varsigma \mu \varepsilon \dot{\tau} \tau \rho)$ ) concept of the "man measure" as entailing that what appears to each person also is with absolute certitude. Cf. Metaph. $\Gamma$, 5.1009a6. See also The Theaetetus of Plato, where Socrates places in the mouth of Protagoras the claim that: «each of us is the measure of the things that are and those that are not; but each person differs immeasurably from every other in just this, that to one person some things appear and are, and to another person other things» (Theaet. 166d2-7 ff.; tr. Fowler 1921).
} 
Journal of Ancient Philosophy ISSN 1981-9471 - FFLCH/USP www.revistas.usp.br/filosofiaantiga
J. anc. philos. (Engl. ed.), São Paulo, v.13, n.2. p. 01-34, 2019.

DOI: http://dx.doi.org/10.11606/issn.1981-9471.v13i2p01-34

\section{Conclusions}

It is now time to draw some conclusive remarks out of the picture sketched so far. In the Ode to Scopas, Simonides seems to defend a lifestyle which is presumably the same embraced by the tyrant Scopas. This leads Simonides to express his personal praise on an ideal of imperfect moral goodness, which is to say, one which departs from the perfect virtue of the man square ( $\tau \varepsilon \tau \rho \alpha ́ \gamma \omega v o \varsigma$ ) in hands and feet and mind. The illustration of the positive aspects of imperfect moral goodness is premised on the thought that extremely hard efforts are needed to acquire perfect virtue in absolute. Most crucially, such efforts prove themselves to be vain if we consider, as Simonides does, that a severely bad luck inevitably ends up affecting the moral outlook of perfectly virtuous people. It is worth noting that Simonides does not mention the possibility that a heavily bad luck never occurs across the human lifespan, to the effect that perfect virtue can be stably preserved. Similarly, he avoids examining the possibility that even an imperfect moral virtue, like perfect goodness, might be amenable to the strikes of bad luck. Those omissions might suggest that the poet means to shift attention to the desirability of an imperfect, less demanding condition of moral goodness, and also that he does so by way of arguments which the Platonic Socrates himself might view as "sophistic". It ought to be noticed, however, that the rigour required of a proper philosophical analysis is missing also in the exegesis of the poem undertaken by the Platonic Socrates in the Protagoras. His professed activity of “correction", just by being a rectification of the poem's content, purposedly fails to restore the original meaning and intentions of the poem.

I have argued that, despite the lack of exegetic rigour, Socrates' attempts are not simply meant to mock a distinctively sophistic attitude towards the interpretation of poetry, but they might help Simonides' readers to bring out authentically Simonidean concepts. As we have seen, although Socrates departs from Simonides when he claims that being permanently virtuous is an easy task, the distinction between "being" and "becoming" (perfectly) virtuous which Socrates ascribes to Simonides might be truly employed by the poet to show that achieving perfect virtue involves efforts is difficult, whereas being stably virtuous is impossible. A second aspect that Socrates seems to rightly emphasise is the idea that sheer avoidance of ugly acts is for Simonides a sufficient condition to qualify an agent as morally good, although in an imperfect sense. Unlike the absolute virtue displayed by the "square" man, the virtue the human type that Simonides 
Journal of Ancient Philosophy ISSN 1981-9471 - FFLCH/USP www.revistas.usp.br/filosofiaantiga
J. anc. philos. (Engl. ed.), São Paulo, v.13, n.2. p. 01-34, 2019.

DOI: http://dx.doi.org/10.11606/issn.1981-9471.v13i2p01-34

describes as "healthy" denotes a minimal condition of moral decency, one which is to be praised simply on the ground that whoever possesses that moral capacity refrains from injustice and harm against other fellow-humans. I have also suggested that Simonides' appeal to the notion of health in a moral sense might evoke the idea of "absence of outstandingness", which the "square" man instead embodies. The Simonidean idea of health is starkly opposed to the Socratic-Platonic one, which denotes only a condition of perfect goodness. As is shown by the discussions undertaken by Socrates with his interlocutors, the idea that fair are those things with which ugly things are not mixed is to be rectified. It might be said, however, that Socrates's exegesis might not be exclusively confined to pave the way for criticism of Simonides' views. His hermeneutical attempt might help the reader to bring out a doublefold anthropological picture of goodness, one in which the ideal of perfect virtue, although professedly noble and possible to achieve, is less practicable than the one embodied by the simply "healthy" one and justifies a departure in expectations. That view, once understood by the Platonic Socrates, might compel him to face the challenge of underlying the risks that might be present in downplaying the consequences of lack of perfect virtue in the democratic life.

Elena Irrera

Università di Bologna

\section{Bibliography}

Adam, J. and Adam, A.M. (1893). Platonis Protagoras. With Introduction, Notes and Appendices. Cambridge: Cambridge University Press.

Arieti, J.A., and Barrus, R.M. (translated and edited by) (2010). Plato's Protagoras. Rowman and Littlefield Publishers: Plymouth.

Barnstone, W. (Translated and annotated by) $\left(2010^{4}\right)$. Ancient Greek Lyrics. Bloomington and Indianapolis: Indiana University Press (first puhlished 1962).

Beresford, A. (2008). "Nobody's Perfect: A New Text and Interpretation of Simonides PMG 542.” Classical Philology 103 (3): 237-256. https://doi.org/10.1086/596516

Bowra, C.M. (1934). "Simonides and Scopas." Classical Philology 29: 230-239. https://doi.org/10.1086/361747 
Journal of Ancient Philosophy ISSN 1981-9471 - FFLCH/USP www.revistas.usp.br/filosofiaantiga
J. anc. philos. (Engl. ed.), São Paulo, v.13, n.2. p. 01-34, 2019.

DOI: http://dx.doi.org/10.11606/issn.1981-9471.v13i2p01-34

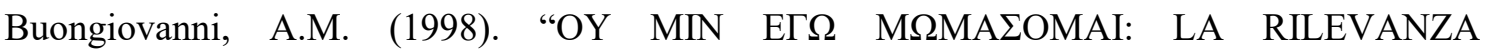
ENCOMIASTICA DI SIMONIDE, "PMG" 542." Studi Classici e Orientali 46 (3): 1033-1047.

Cairns, D. (1993). Aidōs: The Psychology and Ethics of Honour and Shame in Ancient Greek Literature, Oxford: Oxford University Press.

Carson, A. (1992). "How Not to Read a Poem: Unmixing Simonides from 'Protagoras'." Classical Philology 87 (2): 110-130. https://doi.org/10.1086/367294

Coby, P. (1987). Socrates and the Sophistic Enlightenment. A Commentary on Plato's Protagoras. London and Toronto: Associated University Presses.

Cornford, F.M. (1974). Mysticism and Science in the Pythagorean Tradition. In Mourelatos, A.P.D., ed by. The Pre-Socratics: A Collection of Critical Essays. Princeton: Princeton University Press: 135-160.

Crisp, R., ed. by (2000). Aristotle. Nicomachean Ethics, Cambridge: Cambridge University Press.

Del Corno, D. (1988). Letteratura Greca, Milano: Principato.

Denyer N., ed. by (2008) Plato. Protagoras, Cambridge, Cambridge University Press.

Diehl, E., ed. by. (1954), Anthologia Lyrica Graeca. Lipsia: Teubner.

Dickie, M. (1978). "The Argument and Form of Simonides 542 PMG." Harvard Studies in Classical Philology 82: 21-33. https://doi.org/10.2307/311018

Donlan, W. (1969). "Simonides, Fragment 4D and P. Oxy. 2432." Transactions and Proceedings of the American Philological Association 100: 71-95. https://doi.org/10.2307/2935902

Edmonds, J.M., ed. by (1922). Lyra Graeca. Being the Remains of all the Greek Lyric Poets From Eumelus to Timotheus excepting Pindar. London: Heinemann.

Edmonds, J.M., ed. by (1931). Elegy and Iambus (Vol. I), Cambridge, (MA): Harvard University Press, and London: William Heinemann.

Fowler, H.N., ed. by (1921), Theaetetus. In Plato in Twelves Volumes, Cambridge, (MA): Harvard University Press, and London: William Heinemann.

Frede, D. (1986). "The Impossibility of Perfection: Socrates' Criticism of Simonides' Poem in the Protagoras." 39 (4): 729-753.

Freese, J.H., ed. by and translated (1926), Aristotle. Rhetoric. Cambridge and London: Harvard University Press.

Gentili, B. (1964). "Studi su Simonide." Maia 16: 278-304.

Giuliano, F.M. (1992). "Esegesi letteraria in Platone: la discussione sul carme simonideo nel Protagora." 41: 105-190.

Goold, G.P. (1992). Greek Lyric, Vo. IV, Cambridge (Massachusetts), London: Harvard University Press.

Hutchinson, G.O. (2001). Greek Lyric Poetry: A Commentary on Selected Larger Pieces. Oxford: Oxford University Press.

Johnston, R.W. and Mulroy, D.D. (2004). "Simonides' Use of the Term TETPAГ $\Omega N O \Sigma . "$ Arethusa 37 (1): 1-10. https://doi.org/10.1353/are.2004.0006

Kahn, C.H. (1974). "Pythagorean Philosophy before Plato", in Mourelatos, A.P.D., ed by. The Pre-Socratics: A Collection of Critical Essays. Princeton: Princeton University Press: 161-186. https://doi.org/10.1515/9781400863204.161

Lamb, W.R.M., ed. by (1967). Protagoras, in Plato. Plato in Twelve Volumes, Vol. 3. Cambridge, MA: Harvard University Press; London: William Heinemann Ltd. 
Journal of Ancient Philosophy ISSN 1981-9471 - FFLCH/USP www.revistas.usp.br/filosofiaantiga
J. anc. philos. (Engl. ed.), São Paulo, v.13, n.2. p. 01-34, 2019.

DOI: http://dx.doi.org/10.11606/issn.1981-9471.v13i2p01-34

Liddell, H.G., Scott, R., and Jones, H.S. (1996, ninth edition). A Greek-English Lexicon, with a Revised Supplement, Oxford: Clarendon Press.

Noussia Fantuzzi, M., ed. by (2010). Solon the Athenian. The Poetic Fragments. Leiden and Boston: Brill.

Page, D.L., ed. by (1962), Poetae Melici Graeci, Oxford: Clarendon Press.

Parry, H. (1965). "An Interpretation of Simonides 4 (Diehl)", Transactions of the American Philological Association 96: 297-320. https://doi.org/10.2307/283734

Pearson, L. (1962). Popular Ethics in Ancient Greece, Stanford: Stanford University Press.

Pippin Burnett, A. (1985). The Art of Bacchylides, Cambridge (MA) and London: Harvard University Press.

Reale, G. (2000). Platone. Tutti gli Scritti. Milano: Bompiani.

Sauppe, H. and Towle, J.A. (eds.). Protagoras, with Commentary. Boston and London: Ginn \& Co.

Schneidewin, F.W. (1835). Simonides Cei Carminum Reliquiae. Brunswig: Vieweg and Son.

Schütrumpf, E. (1987). "Simonides an Skopas (542 PMG)," Würzburger Jahrbücher für Altertumswissenschaft 13: 11-23.

Schwarts, E. (1951). Ethik der Griechen, Stuttgart: Koehler.

Segal, Ch.P. (1989). "Song, Ritual, and Commemoration in Early Greek Poetry and Tragedy." Oral Tradition 4 (3): 330-359.

Snell, B. (1961). Poetry and Society. Bloomington: Indiana University Press.

Smyth, H.W. (1900). Greek Melic Poets. London, Macmillan and co.

Svarlien, D.A. (translated by) (1991). Bacchylides. Odes. The Annenberg CPB/Project.

Taylor, C.C.W. (translated with notes by) (1976). Plato, Protagoras, Oxford: Oxford University Press.

Vegetti, M., (1989). L'etica degli antichi, Roma-Bari: Laterza.

Wilamowitz-Moellendorff, U. von. (1913). Sappho und Simonides: Untersuchungen über griechische Lyriker. Berlin: Weidmann.

Woodbury, L. (1953). "Simonides on Arete." Transaction and Proceedings of the American Philological Association 84: 135-163. 